\title{
IMÁGENES EN PUGNA. REFLEXIONES EN TORNO A LAS PRODUCCIONES VISUALES INDÍGENAS EN EL ÁMBITO DE LA MINERÍA COLONIAL
}

\author{
CONTENDING IMAGES. REFLECTIONS ON INDIGENOUS VISUAL \\ PRODUCTIONS IN THE COLONIAL MINING CONTEXT
}

PABLO CRUZ

Este trabajo pone su atención en determinadas producciones visuales que se vinculan con aquellos contingentes de mano de obra indígena que resultaron trasladados a los principales centros mineros del espacio surandino durante los primeros momentos de la Colonia. Estas producciones visuales, que se caracterizan por su discreción visual y nivel de abstracción, en marcado contraste con las representaciones y estilos figurativos del "arte colonial andino", reflejarían tanto la acción coercitiva y el control de las imágenes ejercidos sobre estas poblaciones por el régimen y la Iglesia colonial, como el reconocimiento y adopción por parte de las mismas del cristianismo y sus símbolos, la cruz en primer lugar. Los datos aquí vertidos resultan de distintos estudios realizados desde 1995 en diferentes centros mineros y metalúrgicos coloniales del departamento de Potosí, y en regiones de Chuquisaca, Oruro y Pacajes, en Bolivia.

Palabras clave: indígenas del común, minería, metalurgia, Colonia, Andes, Bolivia.

This work focuses on a series of visual productions linked to contingents of indigenous laborers that were sent to work in major mining centers in the Southern Andes during the early part of the colonial period. These visual productions-which are characterized by their visual discretion and level of abstraction, in marked contrast to the figurative representations and styles of "Andean colonial art"-reflect both the coercion and the control of images that the colonial regime and the Church exercised upon these poulations, as well as the latter's recognition and adoption of Christianity and its symbols, above all the cross. The information used in this article comes from a series of studies conducted since 1995 at different colonial mining and metallurgical sites in Potosi Department and in the regions of Chuquisaca, Oruro and Pacajes, in Bolivia.

Keywords: "common" indigenous peoples, mining, metallurgy, Colonial times, Andes, Bolivia.
Este trabajo surge a partir de dos preguntas sobre las producciones visuales indígenas en tiempos coloniales que me formulé durante el Simposio "Formas escriturarias indígenas" en el Ix Congreso Internacional de Etnohistoria, en Arica. Por un lado, ¿porqué algunas imágenes indígenas de fuerte carga simbólica y religiosa no sólo no fueron condenadas en tanto que expresiones idolátricas y sujetas al accionar iconoclasta de la Iglesia, sino que más bien se legitimaron y se generalizaron dentro del régimen colonial? Me refiero aquí tanto al amplio repertorio de representaciones de los antiguos Inkas gobernantes portando emblemas y símbolos de poder vinculados con su condición divina (mascaipacha, borlas, pectorales con la imagen del Sol, licras, etc.), como a aquellos significantes de marcado sentido religioso (serpientes, uturuncos, arcoíris, tokapus, etc.) presentes en celebraciones cívicas y procesiones religiosas, obras pictóricas, escudos nobiliarios indígenas, qeros y otros soportes (fig. 1). Por ejemplo, ¿cómo se entiende la profusión que tuvieron los qeros que plasman estas representaciones y símbolos durante en el siglo xviII cuando ellos mismos se encontraban diabolizados por la Iglesia en razón de su esencia idolátrica, tal como aparece en pinturas como las postrimerías de las iglesias de Carabuco (1684) y Caquiaviri (1739) (fig. 2)? La misma pregunta se puede extender a los escudos de armas de la élites indígenas que representan serpientes y felinos, asociados igualmente con la idolatría. 
Por otro lado, ¿por qué estas mismas representaciones, símbolos y narrativas que refieren al poder político y a la religión de los inkas, no aparecen en las producciones visuales indígenas registradas en los centros mineros coloniales que venimos estudiando en las regiones de Potosí, Lípez, Chichas y Oruro?,

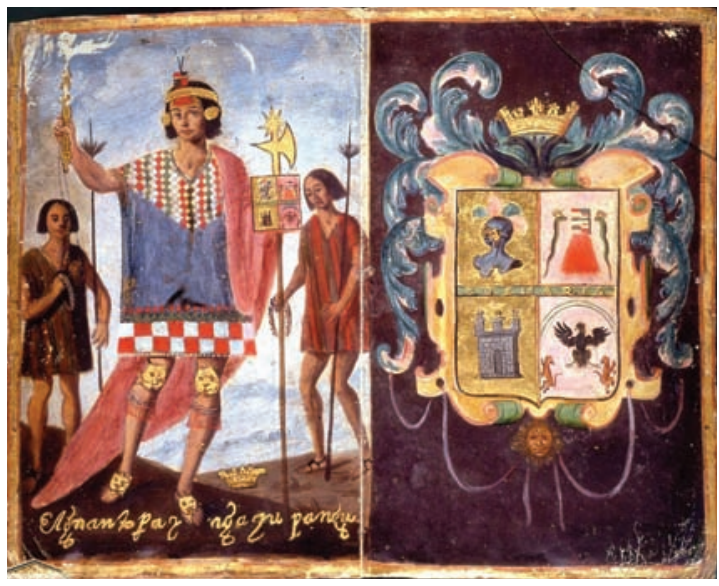

Figura 1. Escudo de armas concedido por el emperador Carlos $\mathrm{v}$ a los descendientes de los incas Gonzalo Uchu Hualpa y Felipe Topa Inga Yupanqui, hijos de Huaina Capac y nietos de Tupa Inga Yupangui (Archivo General de Indias, Mapas y Planos-Escudos, 78). Figure 1. Coat of arms issued by Emperor Charles $v$ to the descendants of the Incas Gonzalo Uchu Hualpa and Felipe Topa Inga Yupanqui, sons of Huaina Capac and grandsons of Tupa Inga Yupangui (Archivo General de Indias, Mapas y Planos-Escudos, 78). ¿por qué no encontramos representaciones del Inka, o diseños que nos remitan a la divinidad del Sol, a la mascaipacha, al arcoíris, uturuncos, tokapus y demás significantes, en los estilos cerámicos y en el arte rupestre de estos enclaves?, ¿qué señalan tales ausencias? $\mathrm{Y}$ al mismo tiempo, ¿cómo se insertaron dentro del concierto colonial las producciones visuales indígenas allí identificadas? Estas preguntas reflejan una de las deudas aun pendientes en los estudios arqueológicos que abordan la Colonia en los Andes: comprender mejor los contextos de vida, procesos sociales y dinámicas culturales que involucraron a aquellas masas de indios comunes, cuyos rostros muchas veces quedaron ocultos en los escritos detrás de caracterizaciones generalistas y aproximaciones elitistas.

Articulando datos arqueológicos e informaciones proporcionadas por las fuentes documentales coloniales, en este trabajo presentamos algunas pistas que contribuyen a responder estas preguntas. Los datos aquí vertidos resultan de diferentes estudios realizados desde 1995 hasta la fecha en el Departamento de Potosí y en regiones de Chuquisaca, Oruro y Pacajes, en Bolivia. Tales estudios estuvieron centrados en la minería y metalurgia prehispánica y colonial temprana, así como en la cartografía religiosa indígena de estos mismos periodos.
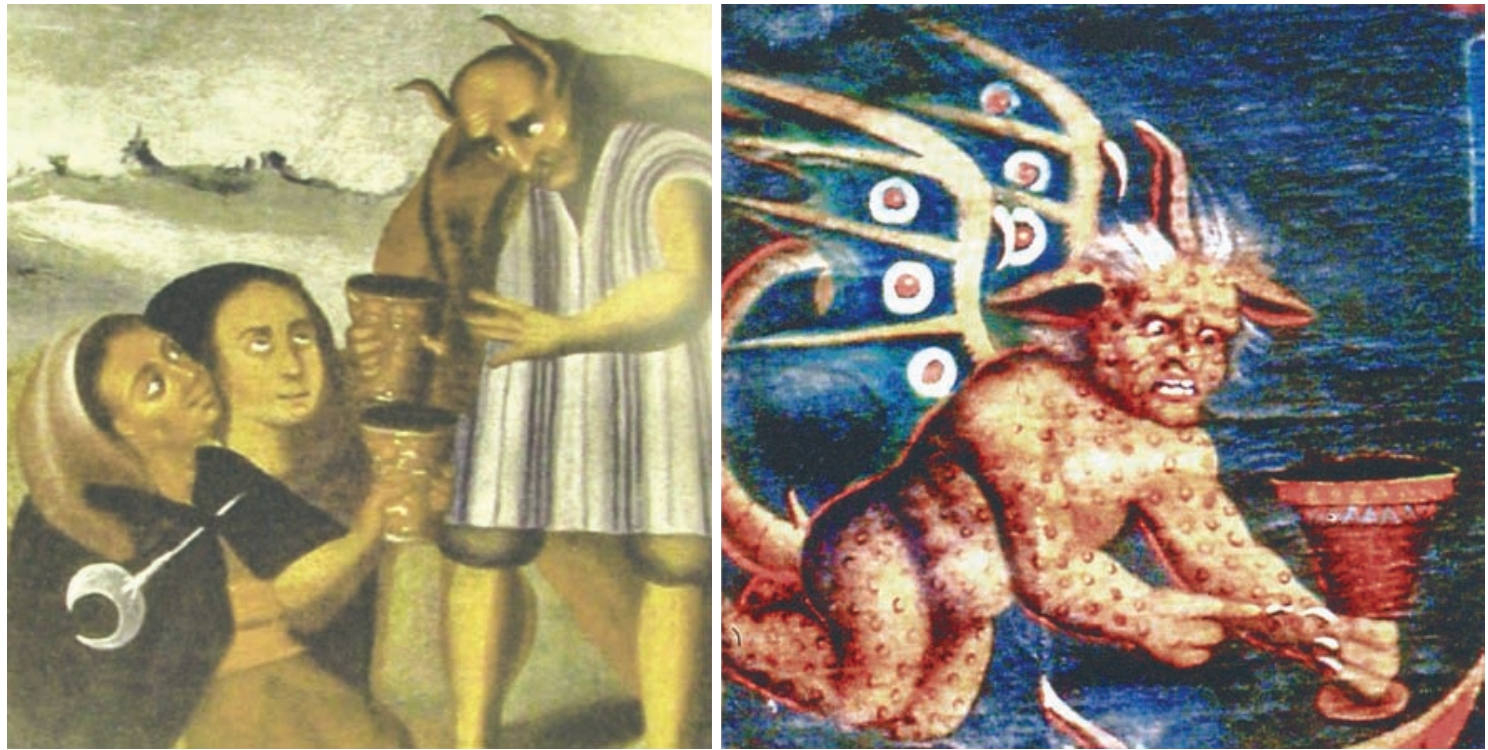

Figura 2. Detalles de los lienzos de "postrimerías" de las iglesias de Carabuco y Caquiaviri. Figure 2. Details of canvases representing the "last days," from the churches of Carabuco and Caquiaviri. 


\section{NOBLEZA INDIANA Y RANCHERÍAS IDOLÁ- TRICAS EN LA VILLA IMPERIAL DE POTOSÍ}

Pocos años después del arribo de los españoles a las costas peruanas, una vez que fueron expoliados los tesoros de los gobernantes indígenas, vaciados sus templos y despojados los pueblos de sus riquezas metálicas, la posesión de las minas surandinas devino uno de los principales argumentos para la conquista y posterior colonización de los Andes. Las minas, motor económico de la empresa colonial, se constituyeron igualmente como importantes escenarios para las pugnas de poder y resistencia que tuvieron lugar entre los españoles -y sus diferentes facciones-, los inkas y demás pueblos indígenas, de suerte que los enclaves coloniales surgidos en torno a ellas reflejan, cada uno en sus momentos dados, una síntesis de lo que significó la conquista y colonización de los Andes, así como el devenir de sus pueblos indígenas. Entre estos enclaves mineros surandinos sobresale la Villa Imperial de Potosí, fundada en 1545 en razón del "descubrimiento" por parte de la Corona de las fabulosas minas de plata del Cerro Rico, aun hoy en día el principal yacimiento argentífero del planeta.

Uno de los temas que resalta en la obra de Bartolomé de Arzáns Orzúa y Vela (1965 [1737]), uno de los más renombrados historiadores coloniales que tuvo Potosí, son las ceremonias y festividades públicas que marcaron eventos de trascendencia: la abdicación y muerte del Rey, la jura del nuevo monarca, el arribo de un nuevo funcionario de la Corona, la construcción de un nuevo templo, la conmemoración de un santo, una celebración religiosa, etc. De manera general, todos estos actos públicos se caracterizaron por una fastuosidad comparable solo con las ciudades del Viejo Mundo, manifestación de la opulencia del mineral de Potosí, pero también del lugar especial que ocupó la Villa Imperial en el diseño del "Nuevo Mundo". En muchas de estas ocasiones ${ }^{2}$ desfilaron representantes del mundo indígena de Potosí y se realizaron representaciones de los antiguos Inkas soberanos, todos ellos ataviados con preciosas vestimentas, insignias y ornamentos en oro y plata. ${ }^{3}$ También desfilaron indígenas portando réplicas de sus armas tradicionales, y se exhibieron mascaradas y carrozas que cargaban con imágenes de estos antiguos gobernantes. Arzáns (1965 [1737] r: 98-99) relata también cómo en 1555, en ocasión de la celebración del Corpus Christi, se estrenaron en Potosí ocho obras teatrales de las cuales cuatro trataban acerca del pasado de los inkas: una de ellas sobre el propio origen de los monarcas, otra sobre los triunfos de Wayna Qhapaq, otra más sobre las tragedias de Cusi Waskar y, finalmente, una sobre el derrumbe del Imperio. Estas tempranas representaciones de los antiguos gobernantes del Tawantinsuyu en los actos y celebraciones de la Villa Imperial estarían entre los antecedentes más antiguos del "inkanismo" que florecería en gran parte de los Andes durante el siglo XVIII (Gisbert 2004), una temática inserta dentro de un programa político destinado a legitimar y reforzar la Corona al mostrar una natural continuidad entre los monarcas Inkas y el Rey (Estenssoro 2003: 164; Macchi 2009: 234).

Pero las representaciones de los antiguos soberanos Inkas en estas celebraciones oficiales no eran solamente alegóricas; muchos de sus descendientes establecieron muy tempranamente residencias en el asiento minero -convertido luego en Villa Imperial-, participando activamente en las labores de la mina. Tal fue el caso de Carlos Inca, hijo de Paullu y nieto de Wayna Qaphaq, quien a pocos años del descubrimiento oficial del cerro, en 1549, aparece en Potosí vinculado con la producción de metales (Medinacelli 2010: 163164) y más tarde como propietario de minas e indios yanaconas (Quisbert 2015). Asimismo, se establecieron en Potosí muchas mujeres pertenecientes a la nobleza inkaica (pallas): las jóvenes solteras (ñustas) se casaron con importantes españoles mineros y otros miembros de las élites indígenas regionales, estableciendo así importantes alianzas familiares. Aparecen igualmente en los primeros años de Potosí varios miembros de la nobleza inkaica del Collao: tal es el caso Baltasar Challco Yupanqui, hijo de Apu Challco Yupanqui, Gobernador del Collasuyo y Ministro del Sol a cargo del Santuario de Copacabana (Quisbert 2015), como también el de Cáceres Viracocha Inga y Bautista Sinchi Atauchi, también nobles inkas vinculados con el Santuario del Titicaca (Medinacelli 2010).

Dos aspectos relacionados entre sí pueden ayudarnos a comprender mejor la presencia de una importante parte de la nobleza inkaica en Potosí. Por un lado, recordemos que en 1545 un miembro de la élite inka, Diego Gualpa, fue quien reveló a los españoles el mineral del Cerro Rico de Potosí (Fuente Sanct Ángel 1965 [1572]), probablemente como fruto de una alianza establecida entre los inkas y una fracción de los españoles leales a la Corona y enfrentada con Gonzalo Pizarro (Santos 
Escobar 1987; Platt \& Quisbert 2008; Cruz \& Téreygeol 2009). Por el otro, y seguramente como parte de esta alianza, la mayoría de la mano de obra indígena empleada en las minas y labores metalúrgicas, al menos hasta finales del siglo Xvi, provenía del Collao y del Cuzco, y muchos de sus alcaldes y capitanes eran miembros de la élite inka (Escobari 2011; Cruz \& Téreygeol 2014). En este sentido, a pocos años de su fundación, el asiento minero de Potosí se convirtió no sólo en uno de los centros de la empresa colonial, sino también -como lo señaló Bouysse-Cassagne (1987: 254)- en un nuevo taypi (centro) para los inkas y miembros de las élites indígenas regionales, incluso un nuevo Cuzco tras la caída del bastión de Vilcabamba en 1571.

Las enormes riquezas del mineral de la "montaña de plata" propiciaron igualmente un florecimiento de las artes y de la ilustración en la Villa Imperial y en otras ciudades como La Plata y La Paz: surgieron escuelas de pintura y escultura, talleres de oficios artesanales y establecimientos educativos como los colegios de la Compañía de Jesús. Los indígenas marcaron su presencia en todos estos espacios de creación artística e intelectual, dejando su impronta en los diferentes matices que adoptaría más tarde el barroco mestizo y que nos son conocidos en la lapidaria, la pintura mural, la talla y la platería destinada a ornamentar iglesias y casas de españoles y nobles indígenas (Gisbert 2004). Entre aquellos artistas indígenas que pasaron por Potosí destaca el nombre de Francisco Tito Yupanqui, creador de la Virgen de Copacabana, un miembro de la élite inka del lago, probablemente hijo de Paullu Inka (Medinacelli 2007). En el amplio repertorio del arte virreinal, largamente dominado por los temas religiosos, las representaciones de indígenas resultan sin duda minoritarias, sobre todo durante el siglo XvI donde son prácticamente desconocidas. Sin embargo, existen referencias sobre dos obras que representaron a los Inkas y sus genealogías, muy probablemente las primeras expresiones del inkanismo señalado más arriba (Wuffarden 2005: 211). Se trata, por un lado, de cuatro paños pintados, encargados por el virrey Francisco de Toledo en 1571 para enviarlo al Rey Fernando II, donde se representa la historia de los inkas junto al retrato de sus soberanos (Levillier 1935; Toledo 1882). De la otra obra es un lienzo cuya descripción aporta Diego Rodríguez de Figueroa, en el cual se representaron diferentes aspectos del cerro y y de la ciudad de Potosí, los retratos de los monarcas españoles, los Inkas gobernantes y otros personajes destacados en la historia de la Villa Imperial, así como también el escudo español y las armas del Inka (Quisbert 1998). Estas armas eran “...un escudo con dos tigres [uturuncu], los cuales tienen encima de sus cabezas el arco del cielo y en medio un árbol, el cual tiene entre las ramas un cóndor, y del árbol está colgado una borla que los ingas traían en la frente con dos plumas por insignias y corona real; a los lados del árbol está por cada parte una culebra..." (Carta de Diego Rodríguez de Figueroa al Virrey Martín de Enríquez, en Quisbert 1998: 158-159).

Tendrían que pasar aun varias décadas para que, desde una perspectiva marcadamente diferente, se conocieran otras representaciones del mundo indígena colonial, así como sobre los Inkas y su historia, por ejemplo en las obras de referencia de Martín de Murúa (2004 [1590]) y de Felipe Guaman Poma de Ayala (1989 [1615]). No obstante, la narrativa inkanista continuaría vigente, manifestándose en las conmemoraciones públicas citadinas y en textos e ilustraciones como las referidas a las armas nobiliarias indígenas. A partir del siglo XVIII tal narrativa se generaliza en la pintura de caballete y mural, con lo que se multiplican las representaciones genealógicas de los Inkas soberanos, los retratos de sus descendientes y de los miembros de las élites indígenas portando vestimentas, ornamentos y emblemas imperiales, como también las representaciones alusivas a relatos o eventos históricos vinculados con estos gobernantes. Estas últimas serían el caso, por ejemplo, de las diferentes pinturas llamadas "Virgen del Cerro", donde la representación del Inka Wayna Qhapaq refiere al mito de descubrimiento de la montaña de Potosí (Gisbert 2004; Cruz \& Téreygeol 2014: 34). En paralelo, se expanden en gran parte del espacio andino representaciones visuales propiamente indígenas en objetos de tradición prehispánica y de fuerte carga simbólica tales como los qeros y pajchas, pero también en otros soportes más banales, como muebles y baúles de diseño europeo. Además de la incorporación de nuevas técnicas y tintes, la influencia europea en este arte indígena se evidencia en el desarrollo de imágenes figurativas, el cual, en el caso de los qeros pintados, expone complejas escenas donde se muestran personajes, relatos míticos y eventos históricos, que en su mayoría rememoran la época de los Inkas (Cummins 2004; Martínez C. et al. 2014). En sintonía con la narrativa inkanista, algunos qeros exponen incluso escudos nobiliarios indígenas, tal el caso del qero $\mathrm{N}^{\circ} 11$ de Copacabana (Posnansky 1945: pl. XXLVII b). 
Ahora bien, hasta aquí hemos tratado sobre algunos aspectos de la élite indígena establecida en Potosí en relación con el discurso inkanista en el arte colonial. Reconocidos sus linajes y derechos de sangre por la Corona, participando activamente en la labor de las minas y en la producción de metales, miembros de esta élite, formalmente convertidos al cristianismo, refinados y con cierto nivel de ilustración, no solo se integraron plenamente dentro del régimen y economía colonial, sino que vieron acrecentar sus riquezas y dominios políticos. La gravitación que tuvo esta élite en los paisajes sociales de las urbes coloniales explica su gran visibilidad histórica e historiográfica.

Contrariamente, poco sabemos sobre la vida de aquellos indígenas del común, quienes constituyeron, en todo momento, la principal población de Potosí y el eslabón crítico en la producción minera. ${ }^{4}$ Salvo casos puntuales, ellos aparecen en las fuentes documentales de manera anónima bajo la categoría genérica de "indios" o bien formando parte de colectivos étnicos, regionales o laborales (p. e. aymaras, collas, yanaconas, mitayos). Sus representaciones aparecen sólo en contadas pinturas que refieren a la producción de metales, como las acuarelas que muestran indios fundiendo mineral en wayras, ${ }^{5}$ trabajando en un ingenio ${ }^{6}$ o, posteriormente, en tanto que miniaturas presentes en planos y paisajes descriptivos de la ciudad y montaña de Potosí. ${ }^{7}$ En estas obras, sus siluetas anónimas y difusas aparecen como "hormigas" que suben y bajan del cerro según la expresión de Gisbert y Mesa (1977: 239, en Godoy Vega 2012: 61). Una vez trasladados de sus lugares de origen, estos indígenas fueron establecidos en rancherías ubicadas alrededor del casco urbano y organizadas en torno a catorce parroquias de indios (Capoche 1959 [1585]: 140; Ocaña 1987 [1605]: 175 y ss.). Sus viviendas son descritas por Ocaña (1987 [1605]: 169) como "[...] pocilgas o zahuradas de puercos; unas piedras puestas por la mayor parte en redondo con un poco de barro y por otra parte de arriba con paja, y tan baja que apenas se puede estar de pie [...]". Excavaciones realizadas en el ingenio de San Marcos, a escasos metros de la parroquia de indios de San Francisco, pusieron en evidencia uno de estos hogares, de planta circular y construida con muros simples de piedra, tal como señala la fuente. De manera significativa, los pisos de la vivienda, al igual que la totalidad de las superficies exhumadas, se hallaban intensamente contaminadas por lamas (sedimento mineral resultante de la trituración de las menas) y mercurio, un testimonio de las precarias condiciones de vida que sufrió esta masa de indígenas anónimos. Igualmente, en contraste con la hidalguía atribuida a la nobleza inkaica y demás élites indígenas, estos indios del común aparecen muchas veces en las fuentes documentales como uno de los terrenos más fértiles para todo tipo de vicios y pecados: sobresalen las borracheras, bailes y diversas idolatrías que en varios casos nos remiten a las descripciones sobre el movimiento mesiánico conocido como Taqui Oncoy (Millones 1990; Saignes 2003). ${ }^{8} \mathrm{Al}$ igual que los qeros, pero con distintas repercusiones, estas borracheras y bailes fueron diabolizados en obras religiosas como las postrimerías de Carabuco y Caquiaviri citadas anteriormente. Pero además de promover la idolatría, las borracheras impactaron negativamente en las labores de la mina, al punto que se procuró -y se logró por un corto periodo-, prohibir en Potosí el ingreso de harina de maíz, ingrediente principal para la elaboración de la chicha, ${ }^{9}$ considerada ya como un brebaje del demonio. ${ }^{10}$ Las fuentes vinculan a estos indios del común con una serie de lugares propicios para la idolatría ubicados en los alrededores de la Villa Imperial, de los cuales la Quebrada de San Bartolomé es el más afamado. Identificada en tiempos prehispánicos bajo el nombre de Mullupunku, se trata de un portal de ingreso a la montaña de Potosí y la jurisdicción del waḱa de Porco, considerado incluso como una de las entradas al propio infierno (Cruz 2006; Absi \& Cruz 2007). Con menor renombre, otros espacios vinculados con los cultos idolátricos fueron Tarapaya, Karachipampa y el Arenal, llamado antiguamente Ttio, actualmente el barrio San Roque, ${ }^{11}$ así como también los waycos (quebradas), espacios ocultos por el relieve montañoso donde los indios lograron refugiarse del yugo de la mina, en ocasiones con la complicidad de sus caciques. ${ }^{12}$ Finalmente, en lo que respecta al origen de esta población indígena asentada en Potosí, como ya fue señalado, las fuentes concuerdan en destacar aquella mano de obra procedente del Collao y del Cuzco, y en menor medida de regiones vecinas como Carangas, Lípez, Chichas, etc. (Capoche 1959 [1585]; Espinoza Soriano 1972, entre otros). Se sumaron a estos contingentes de indios los Qaraqara y los Charka, establecidos en la región con anterioridad a la llegada de los españoles (Platt et al. 2006; Cruz \& Absi 2008). Tras las sucesivas caídas del mineral de Potosí, sobre todo a partir de los primeros años del siglo XVII, parte de esta población indígena se trasladó a otras minas "descubiertas" por entonces en la región: Esmoraca (1603), Oruro (1606), Garci Mendoza (1606), Chocaya (1630) y San Antonio de Lípez (1647?). 
En sintonía con las informaciones brindadas por las fuentes, en Potosí y en otros enclaves mineros coloniales, se registraron estilos cerámicos que refieren tanto a los inkas como a la masa de indígenas procedentes del Collao. Por un lado, se trata de estilos de tradición prehispánica que continuaron vigentes durante el siglo xvi y las primeras décadas del XVII, entre los que se encuentran la cerámica inka (regional e imperial), estilos regionales como el Pacajes, Chilpe y aquellos identificados como Colla o Altiplánico (Cruz \& Téreygeol 2014: 26-29), además de tradiciones locales que varían en función de la localización del sitio (p. e. el grupo Qaraqara en Potosí y Mallku en los Lípez). ${ }^{13}$ Por otro lado, se trata de dos estilos contemporáneos, que denominamos como Qolla Tardío I y II, los que si bien se muestran en continuidad con los estilos prehispánicos, resultarían propios de los primeros momentos de la Colonia. Mientras el estilo Qolla Tardío I, en el que predominan los diseños de espirales, se vincularía con la cerámica Chilpe, el Qolla Tardío II nos conduce directamente al altiplano circumlacustre, donde fue identificado bajo diferentes nombres (Cruz \& Téreygeol 2014). ${ }^{14}$ Aparte de estos estilos, se generalizan progresivamente durante este periodo cerámicas rústicas $y$, posteriormente, cerámicas con superficies vitrificadas.

Dos aspectos de los estilos Qolla I y II resultan relevantes. Por un lado, ellos fueron registrados en contextos relacionados con la producción de metales en Potosí, Porco, San Antonio de Lípez, Chocaya, Garci Mendoza, Oruro y Berenguela de Pacajes. En el caso de Potosí ambos estilos se identificaron tanto en espacios metalúrgicos con wayras (huayras, huayrachinas) como en áreas vinculadas con ingenios hidráulicos (cf. Agua de Castilla, Ingenio San Marcos, Ingenio Ichuni), mientras que en los restantes centros mineros, de menor escala, se los halló en todos los sectores, incluso en San Antonio de Lípez, al interior de una mina colonial abandonada. Por otro lado, las excavaciones realizadas en el paraje de Jesús Valle, situado al norte de la ciudad de Potosí, pusieron en evidencia un taller alfarero, con una significativa presencia de material inka, en donde fueron fabricadas cerámicas de los estilos Qolla Tardío I. Esto quiere decir que, si bien se trata de estilos altiplánicos, al menos en el caso de Potosí y en lo que respecta al Qolla Tardío I, se registra una producción local. Dos fechados realizados a partir de muestras tomadas en este taller alfarero arrojaron como resultado 1480-1646 AP $(95,4 \%)$ y $1510-1600$ (56\%), lo que resulta en una curva que es más homogénea en la segunda mitad del siglo xvI
(Cruz \& Absi 2008). Si bien en estos centros mineros coloniales predominan los estilos cerámicos indígenas, es importante señalar aquí que, en una proporción considerablemente menor, aparecen igualmente fragmentos de cerámicas de origen español, generalmente vajillas refinadas. Incluso, y prueba de una mundialización incipiente, en el asiento de San Antonio de Lípez hemos hallado un fragmento de una cerámica china del siglo xVII (camaieu blue de chinnoiserie).

\section{PRODUCCIONES VISUALES INDÍGENAS EN EL ÁMBITO MINERO COLONIAL}

Partiendo de los registros obtenidos en Potosí y sus inmediaciones, los cuales fueron cotejados con informaciones obtenidas en otros enclaves minero-metalúrgico coloniales del espacio surandino, trataremos a continuación sobre algunas características de las producciones visuales indígenas vinculadas con estos espacios productivos. Básicamente, tales producciones visuales se encuentran en los estilos alfareros antes descritos, así como en diferentes soportes rupestres.

Los estilos identificados como Qolla Tardío I y II reflejan algunas continuidades a la vez que transformaciones con respecto a los precedentes estilos prehispánicos. En el Qolla Tardío I, presente sobre todo en vasijas globulares y en pucos y platos con superficies alisadas, se mantienen los diseños de espirales en negro sobre el fondo natural característicos del estilo Chilpe, los que en algunos casos se transforman en remates espiralados de volutas y/o espirales reticuladas. Por su parte, el estilo Qolla Tardío II, hallado principalmente en pucos y platos con superficies pulidas o con engobes rojizos, ${ }^{15}$ muestra un repertorio más amplio de diseños pintados en negro o en negro y blanco. Por un lado, se encuentran diseños de espirales semejantes a los anteriormente descritos, los que pueden contener puntos blancos sobre el trazo negro. Por el otro, diseños de líneas rectas perpendiculares sobre el borde, así como de líneas ramiformes y líneas zigzagueantes con puntos blancos intercalados. Aparecen también diseños figurativos con diferentes niveles de estilización que muestran generalmente siluetas de animales como camélidos y aves, y, con menor frecuencia, animales fantásticos cuyas siluetas draconiformes nos remiten al amaru andino. Como en los casos anteriores, tales diseños figurativos fueron realizados en negro, o en negro con puntos blancos. Finalmente, en la cerámica rústica se 
destacan vasijas asimétricas portando en sus asas y/o en sus cuerpos pequeños apliques de contorno serpentiforme.

\section{Producciones visuales rupestres}

Nos referimos aquí a producciones visuales rupestres, en lugar de la fórmula generalizada de arte rupestre, en un sentido amplio y no excluyente que suma otras modalidades y técnicas expresivas que las pinturas y los grabados. Como lo veremos a continuación, una de las principales características de estas producciones visuales, a diferencia de lo que sucede con el arte rupestre prehispánico de la región, es su discreción visual.

A pesar de los siglos que transcurrieron, y del importante crecimiento urbanístico y poblacional que tuvo lugar en las últimas décadas, se conservan en los alrededores inmediatos de Potosí algunos lugares con diseños rupestres coloniales. Estos lugares son: la Quebrada de San Bartolomé, el faldeo norte del Cerro Rico, Tikaloma, Estancia Karachipampa, Agua de Castilla y Samasa Cueva. De una manera u otra, se trata de espacios que tuvieron hasta años recientes $-\mathrm{y}$ en algunos casos la siguen teniendo, como la Quebrada de San Bartolomé- una fuerte connotación simbólica y religiosa, una de las razones que puede explicar su perduración en el tiempo. Como fue señalado antes, el más célebre de estos espacios fue la Quebrada de San Bartolomé, un hito de importancia en la cartografía religiosa de esta parte de los Andes desde tiempos prehispánicos. No trataremos aquí sobre este sitio, ya que es el mismo objeto de otros trabajos anteriores (p. e. Cruz 2006; Absi \& Cruz 2007, en que se explica cómo la Quebrada de San Bartolomé, Tika Loma, Estancia Karachipampa y Samasa Cueva fueron espacios que marcaron accesos a la Villa Imperial, vinculados con caminos que condujeron respectivamente a La Plata -hoy Sucre- y valles chuquisaqueños y a la región de Chichas). No obstante, no disponemos de elementos suficientes para saber si estos espacios se constituyeron en el pasado como punkus, como el caso de la Quebrada de San Bartolomé. Tika Loma, hoy en día un barrio periurbano, se ubica sobre el faldeo de la serranía de Kari Kari, al este de la ciudad de Potosí. Sobre una cresta de este faldeo, sometida constantemente a fuertes vientos, se registraron los restos de antiguas actividades metalúrgicas con uso de wayras asociadas con los estilos cerámicos referidos anteriormente. Se trata igualmente de un espacio que acoge una prolongada e intensa actividad ritual, en la

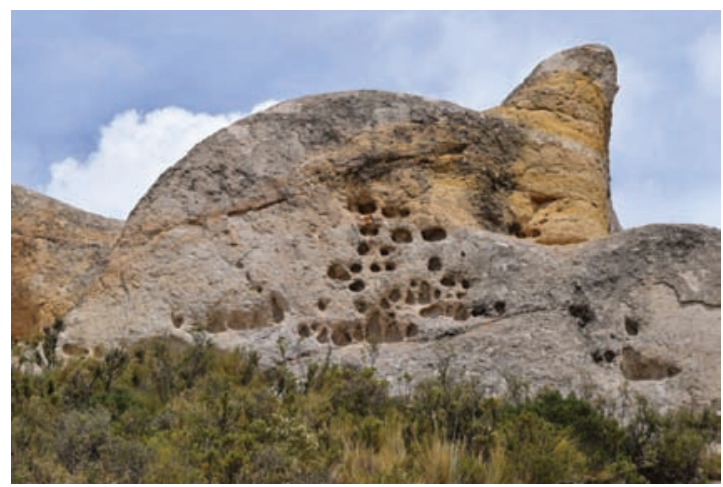

Figura 3. Estancia Karachipampa, peña con oquedades naturales formatizadas ubicada junto a un antiguo camino que conduce al Cerro de Potosí. Figure 3. Estancia Karachipampa. Crag with natural cavities shaped further by humans, situated alongside an old road that leads to Cerro de Potosí.

actualidad sobre todo ofrendas y sacrificios ligados con la brujería urbana. Las producciones visuales coloniales se hallan en las paredes orientales de este afloramiento rocoso, inmediatamente por debajo de aquellos espacios donde funcionaron las wayras. Se trata de dos conjuntos de horadados o perforaciones, uno mostrando diez agujeros, y el otro dieciséis, dispuestos sin un orden aparente sobre la pared vertical. Otros horadados individuales, así como raspados de cruces y letras, están diseminados de manera aislada en diferentes sectores de este afloramiento. Puesto que hoy en día toda esta área objeto de una intensa dinámica de asentamiento de migrantes oriundos de la región de Tinquipaya, es posible que otras producciones visuales semejantes resultasen recientemente destruidas. Por debajo del afloramiento de Tika Loma discurre un pequeño valle que comunica con las planicies de Karachipampa y que constituyó antiguamente una de las principales vías de acceso a la Villa Imperial. En este valle de montaña sobresalen una serie de afloramientos de coloración blanquecina y siluetas tortuosas, ubicados principalmente al pie de del cerro Thara Qaqa ("peñas desdentadas"), nombre en quechua que refiere al aspecto intrigante de tales formaciones. Uno de estos afloramientos, que sobresale por su singular silueta junto a la ruta, expone varios conjuntos de horadados y oquedades de diferente tamaño y forma. Si bien varias de estas oquedades pudieron tener un origen natural, muchas de ellas ofrecen señales de haber sido regularizadas, formando contornos circulares y nichos trapezoidales (fig. 3). Por encima de esta formación, se localiza una roca que expone en una de sus paredes una 
serie de grabados poco visibles, en los cuales se identifican las siluetas de al menos dos cruces con pedestal. Otra roca, ubicada a escasos metros al norte de la anterior, muestra un conjunto de grabados superficiales, de los cuales al menos siete tienen un contorno circular, así como restos de un diseño serpentiforme producidos por termoalteración. De manera significativa, en ambas rocas los diseños rupestres están visualmente vinculados con la silueta del Cerro de Potosí (fig. 4). Por su parte, Samasa Cueva ("cueva de descanso") es un abrigo inserto en un afloramiento rocoso ubicado en la baja ladera del cerro Huacajchi, al sur de Potosí, a escasos metros de la antigua ruta que comunicaba con la región de Chichas. Como su nombre lo indica, el sitio fue utilizado como lugar de descanso y pernocte en las travesías caravaneras hacia y desde Potosí. Una cruz pintada fue registrada en el interior del abrigo, y los trazos raspados de al menos cinco cruces en su exterior. Los otros registros se enmarcan en contextos vinculados con la producción minera y metalúrgica. Por un lado, en la parte baja del faldeo norte del Cerro Rico, en una zona igualmente afectada por el crecimiento urbano de la ciudad, se registraron dos rocas presentando perforaciones en sus caras. Una de ellas es un pequeño afloramiento, cuya silueta se asemeja a la de la montaña, en el que se observan al menos diez perforaciones. Como aparece en la fotografía (fig. 5), la roca fue intensamente sometida a la acción del fuego como resultado de las prácticas rituales llevadas en torno a la misma, las cuales se extendieron hasta tiempos recientes. La otra roca, recientemente removida por trabajos de suelos, expone un total de veintiséis perforaciones dispuestas de manera aleatoria sobre una de sus caras (fig. 6). Por otro lado, un conjunto de imágenes rupestres fue identificado en el páramo denominado Agua Castilla, sobre las faldas de la serranía de Kari Kari, cerca de tres instalaciones metalúrgicas coloniales que formaron parte de la "ribera de los ingenios". En total se registraron cinco rocas portando grabados rupestres y una con una serie de siete horadados alineados. En todos los casos, los grabados rupestres muestran diseños figurativos, entre los cuales se destacan diversas representaciones de cruces (simples, en pedestal, con y sin remates, etc.), así como representaciones antropomorfas asociadas con éstas (fig. 7). De la misma manera que en los registros referidos anteriormente, estas rocas con grabados figurativos se encuentran visualmente asociadas con la silueta de la montaña de Potosí (fig. 8).

Así como sucede con los estilos cerámicos, rocas con horadados y/o perforaciones semejantes a las observadas en Potosí fueron halladas en otros enclaves minero-metalúrgicos: Cantumarca (Potosí), Rumi Campana (Oruro), San Antonio de Lípez (Sud-Lípez), Chocaya (Chichas) y Garci Mendoza (Intersalar) (fig. 9). De este conjunto, destacan por sus semejanzas aquellas de Rumi Campana, las cuales se ubican al pie de las minas coloniales del cerro San Cristóbal, en las cercanías igualmente de un ingenio del mismo periodo (fig. 10). Por otro lado, en Berenguela y Corocoro de Pacajes se identificaron oquedades formatizadas, algunas en forma de nichos, en paredes y afloramientos rocosos, semejantes a los registrados en las peñas de Karachipampa (figs. 11 y 12). Por su parte, en las áreas mineras de San Antonio de Lípez y Tholapampa se registraron nume-
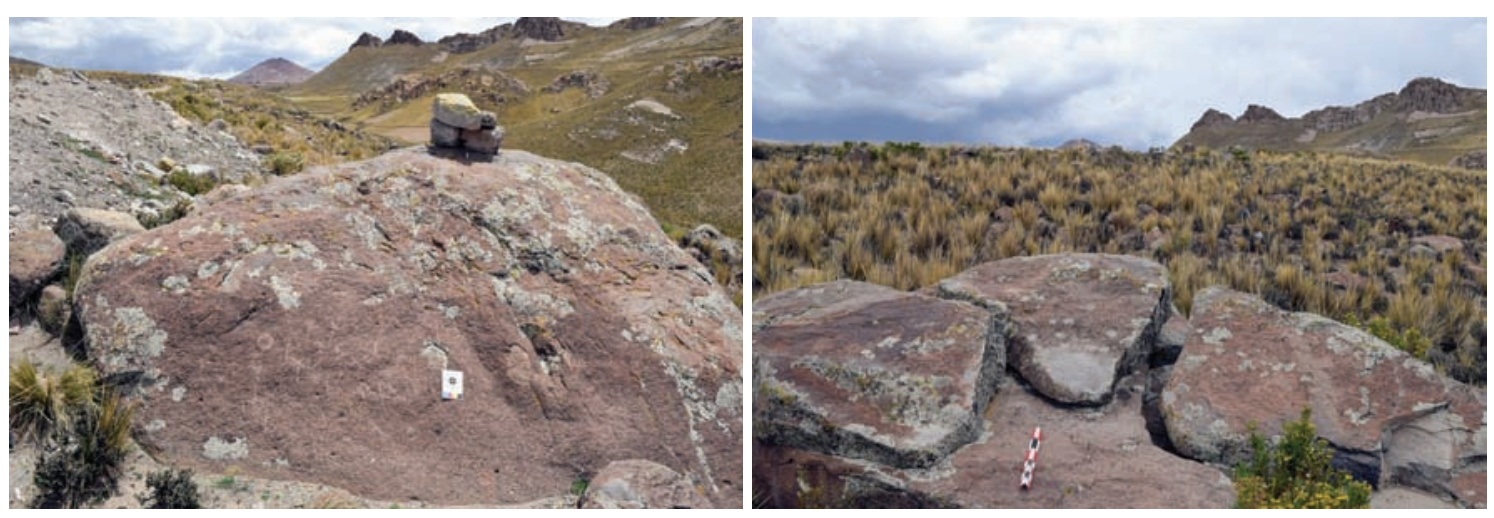

Figura 4. Estancia Karachipampa, rocas portando grabados de cruces y otros de contorno circular vinculadas visualmente con la silueta del Cerro de Potosí (al fondo de las fotos). Figure 4. Estancia Karachipampa. Rocks bearing engravings of crosses and circular figures linked visually with the outline of Cerro de Potosi (in the background of the photographs). 

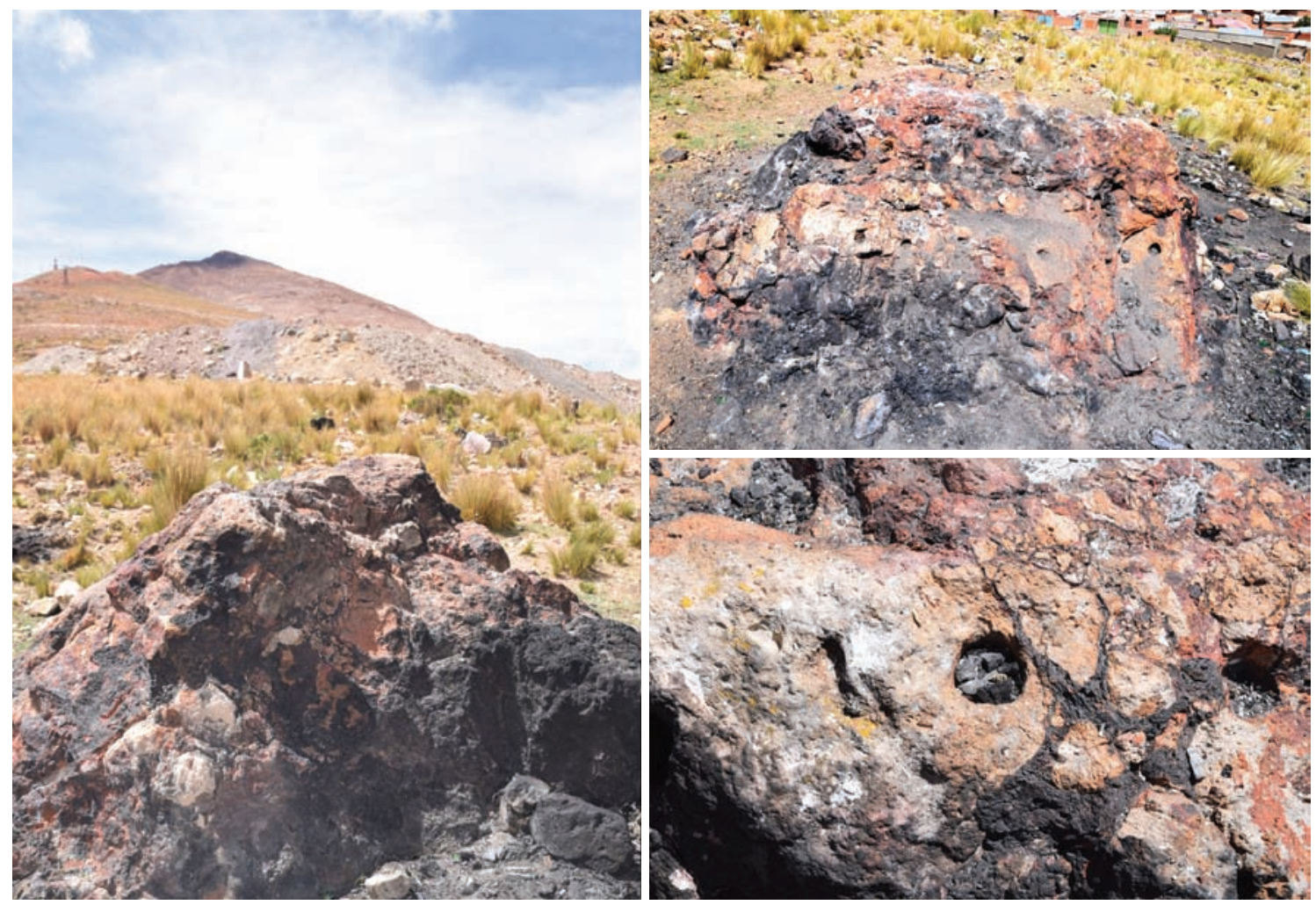

Figura 5. Faldeo norte del Cerro de Potosí, roca portando un conjunto de 10 perforaciones, en la actualidad objeto de prácticas rituales. Figure 5. Northern slope of Cerro de Potosí. Rock bearing a series of 10 drilled holes, currently used for rituals.

rosas rocas con diseños serpentiformes, la mayoría de ellos producidos por aplicación de una fuente de calor, similares al único caso identificado en Karachipampa (Cruz 2015). Finalmente, representaciones de cruces cristianas, diseños frecuentes en el arte rupestre andino, fueron registradas en todas las localidades mineras citadas, aunque solamente en Potosí, Thola Pampa y San Antonio de Lípez se registraron cruces con pedestal y/o remates, y asociadas con otros diseños figurativos (fig. 13). De manera significativa, en San Antonio de Lípez se registraron diseños de cruces en elementos activos de quimbaletes y en rocas portando horadados y diseños serpentiformes, algunas de ellas mostrando evidencias de una destrucción intencional (figs. 14 y 15).

Como hemos visto, algunas producciones visuales registradas en Potosí se encuentran visualmente relacionadas con el Cerro Rico, considerado en tiempos prehispánicos como un importante wak'a regional (Gisbert 2004; Bouysse-Cassagne 2004, 2005, 2008). Tal relación entre producciones visuales rupestres y cerros sacralizados aparece igualmente en otros encla-

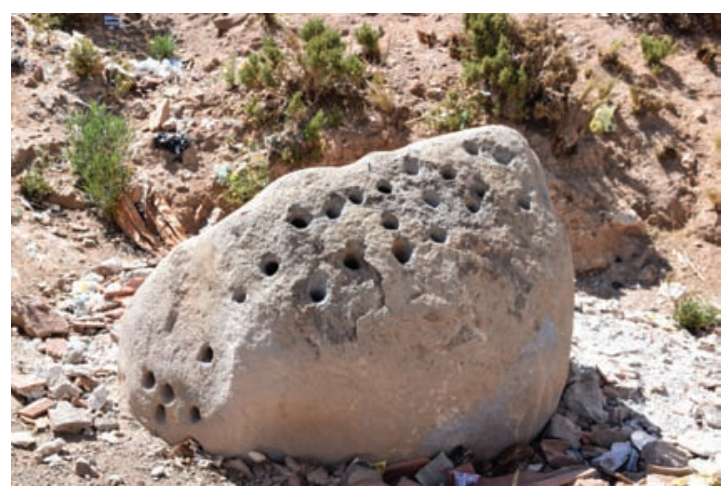

Figura 6. Faldeo norte del Cerro de Potosí, roca portando un conjunto de 26 perforaciones recientemente removida. Figure 6. Northern slope of Cerro de Potosí. Recently moved rock bearing a series of 26 drilled holes.

ves mineros coloniales, como San Antonio de Lípez y Tholapampa. En San Antonio se trata de un conjunto de dieciocho rocas que portan diseños serpentiformes y horadados distribuidas a lo largo de un trayecto que se direcciona al cerro Lípez (6.000 msnm), mientras 


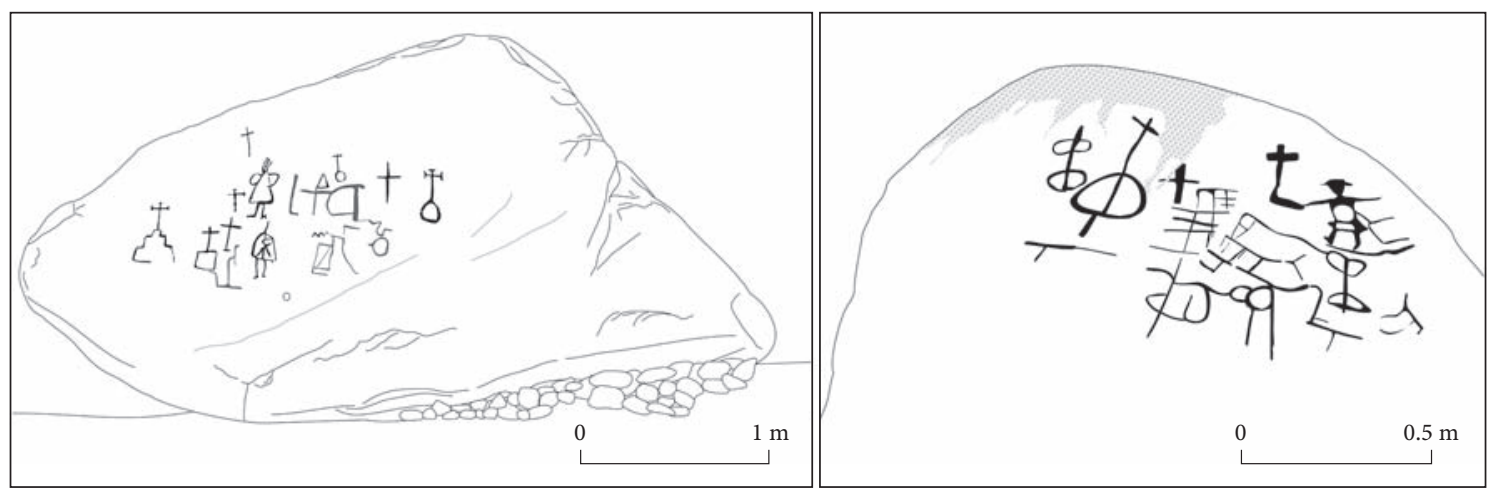

Figura 7. Agua de Castilla, faldeo del Kari Kari, relevamientos de rocas portando grabados representando diferentes tipos de cruces. Figure 7. Agua de Castilla, the slope of Kari Kari. Sketches of rocks bearing engravings of different kinds of crosses.
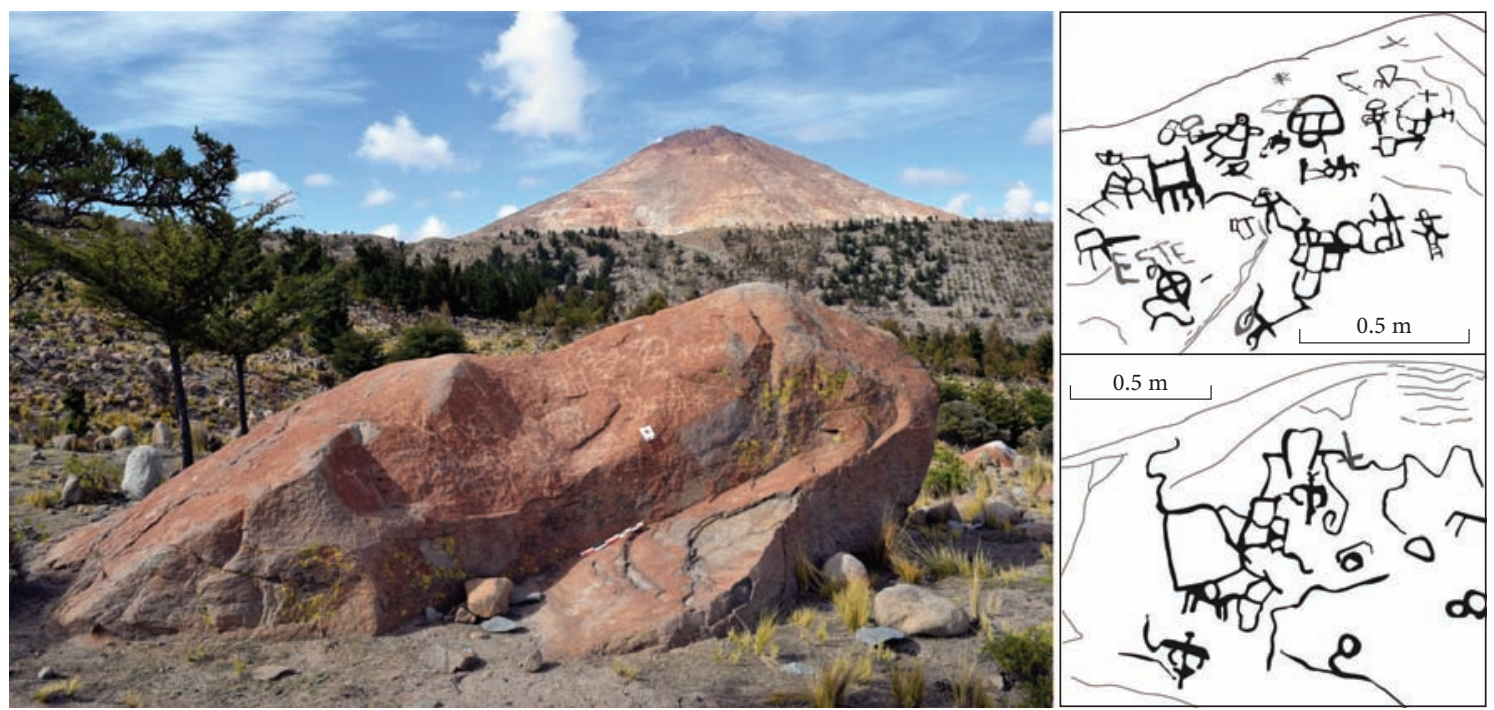

Figura 8. Agua de Castilla, faldeo del Kari Kari, roca con grabados rupestres asociada visualmente con el Cerro de Potosí. Nótese la mimesis entre la roca y la silueta de la montaña. Figure 8. Agua de Castilla, slope of Kari Kari. Rock with engravings visually associated with Cerro de Potosí. Note the mimesis between the rock and the outline of the mountain.

que en Tholapampa se registraron tres rocas con diseños serpentiformes y horadados vinculadas con el Cerro Cosuña (5.200 msnm) (Cruz 2015). Este tipo de producciones visuales rupestres sería particular al ámbito minero de comienzos del periodo Colonial, y estaría vinculado con antiguos cultos a los cerros minerales, apareciendo igualmente relacionados con algunos cerros minerales de la región que albergan en sus cumbres adoratorios de altura inkaicos. ${ }^{16}$ Tal es el caso del Cerro Cuzco (5.400 msnm), en la cordillera de Los Frailes, en cuya cumbre se alza un adoratorio de altura inka asociado con minas superficiales, fechado por AMs en 1400-1465 (95\%) (Cruz et al. 2013: 103). $\mathrm{Al}$ igual que en los casos anteriores, se identificaron en este cerro un conjunto de ocho rocas portando diseños serpentiformes y horadados, los cuales estarían marcando un trayecto entre la base del cerro y el adoratorio. Finalmente, en las laderas del cerro Tunupa (5.350 msnm), un volcán localizado en la ribera norte del salar de Uyuni, se identificó un total de catorce rocas portando semejantes producciones visuales, de las cuales once están dispuestas como marcando un trayecto entre la base del cerro y su cumbre (Cruz 2015). Aunque en este cerro no se logró identificar explotaciones mineras, sí se registraron espacios metalúrgicos en contextos inkas en los sitios de Alianza y Jirira Vinto, ambos al pie de la montaña. 

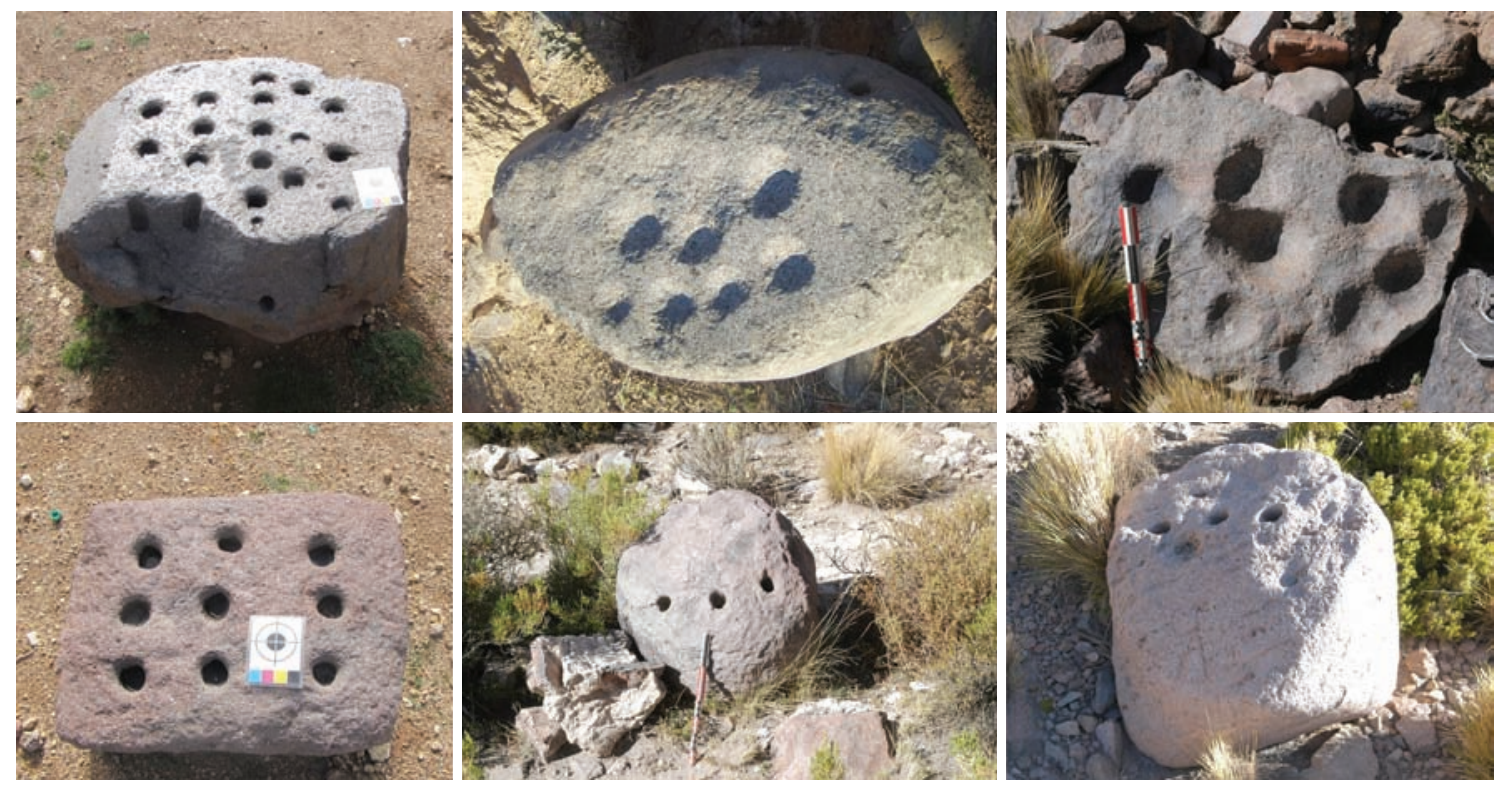

Figura 9. Distintas rocas portando conjuntos de perforaciones registradas en distintos establecimientos mineros: Chocaya (izquierda arriba y abajo), Cantumarca (centro arriba), Garci Mendoza (centro abajo), Guayco Seco, San Antonio de Lípez (derecha arriba y abajo). Figure 9. Rocks bearing a series of drilled holes recorded at different mining establishments: Chocaya (top and bottom left), Cantumarca (top center), Garci Mendoza (bottom center), Guayco Seco, San Antonio de Lipez (top and bottom right).

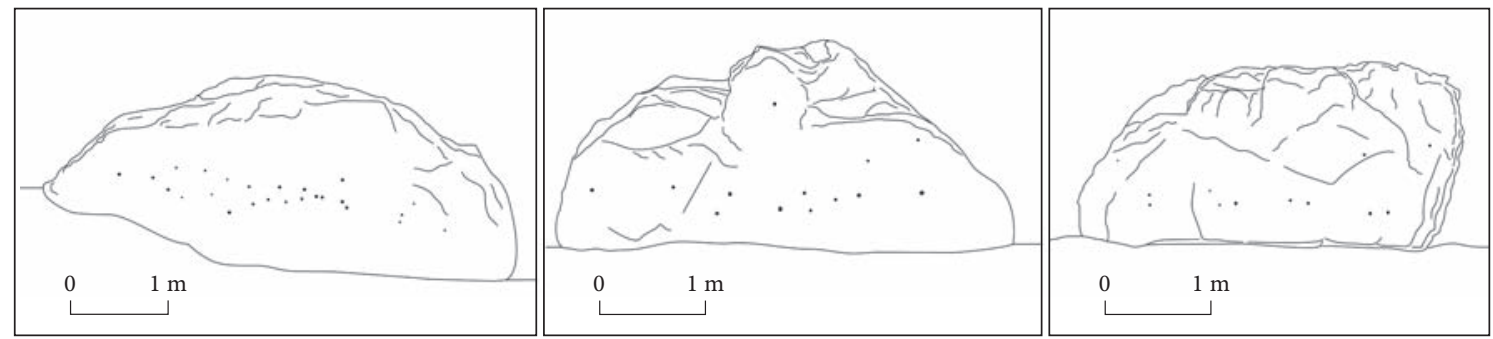

Figura 10. Cerro San Cristóbal-Rumi Campana, Oruro, rocas portando conjuntos de perforaciones. Figure 10. Cerro San Cristóbal-Rumi Campana, Oruro. Rocks bearing multiple drilled holes.

\section{DISCUSIÓN}

Las imágenes y producciones visuales indígenas registradas en Potosí y otros enclaves mineros coloniales que abordamos en este trabajo pueden resultar poco relevantes, atractivas o sofisticadas, en comparación con la exuberancia técnica y expresiva del "arte colonial", como también con respecto al "arte indígena" que se expresa en qeros y textiles, entre otros soportes. Incluso, producciones visuales como horadados, perforaciones y líneas serpenteantes podrían no ser consideradas como tales, sino más bien como meros resultados de prácticas rituales y/o gestos técnicos particulares. Pero más allá de cualquier apreciación clasificatoria, estética o valorativa, siempre cargadas de subjetividades, es en estos contrastes que encontramos algunos elementos de respuestas a las dos preguntas formuladas en el inicio de este trabajo.

Lo primero que hay que destacar es que en estos contextos coloniales vinculados con la minería coexistieron al menos dos poblaciones indígenas netamente diferenciadas entre sí. Por un lado, la élite indígena compuesta por descendientes de la nobleza inkaica y linajes regionales, indígenas acaudalados e indígenas que cumplieron funciones destacadas en el nuevo régimen colonial. Por el otro, la enorme masa de indios del común, compuesta por yanaconas, mitayos y arrieros afectados a la labor de las minas y sitios metalúrgicos, 

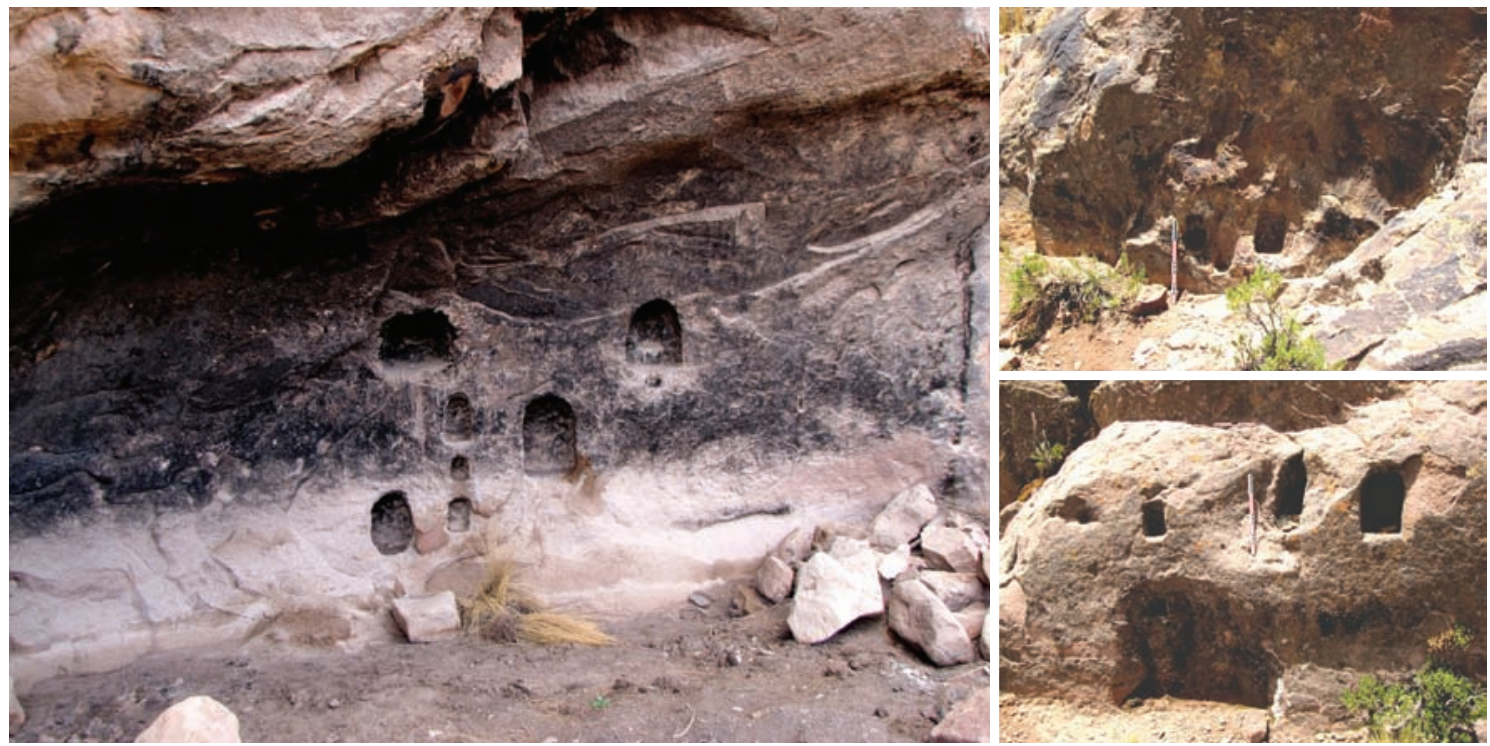

Figura 11. Berenguela de Pacajes, nichos y horadados en el interior de un alero y en paredes rocosas en espacios mineros y metalúrgicos. Figure 11. Berenguela de Pacajes. Niches and boreholes inside a rock shelter and on rock walls at mining and metallurgical sites.

como también por agricultores y pequeños comerciantes que se establecieron en los centros mineros junto con sus familias. En Potosí, unos vivieron en cómodas casas del casco urbano, con portales ornamentados con sus símbolos y blasones nobiliarios, dominaron el idioma de los colonos y participaron de la vida cultural y religiosa de la ciudad. Establecidos en indiferenciadas rancherías ubicadas en la periferia, poco se conoce sobre las vidas de los otros, más allá de sus labores, las condiciones miserables de sus vidas, sus borracheras y prácticas idolátricas. Los primeros se beneficiaron de la labor de las minas acumulando riquezas y poder político, mientras que los otros entregaron masivamente sus cuerpos a estas labores, perdiendo frecuentemente sus vidas en el interior de los socavones o por causa de las tóxicas emanaciones de los hornos de fundición. Tan marcados fueron los contrastes entre ambas poblaciones de indígenas que las categorías genéricas de "indios", "indígenas", "sociedad indígena", "arte indígena", como también "inka", "aymaras", etc., aplicadas a estos contextos coloniales, pueden resultar tan vagas como inverosímiles. Y es que más que tratarse de segmentos o clases de una misma sociedad indígena estratificada, estas dos poblaciones indígenas constituyeron diferentes sociedades dentro de un mismo sistema colonial fuertemente jerarquizado, en donde sin duda una prevaleció sobre la otra. No por ello una población fue más (o

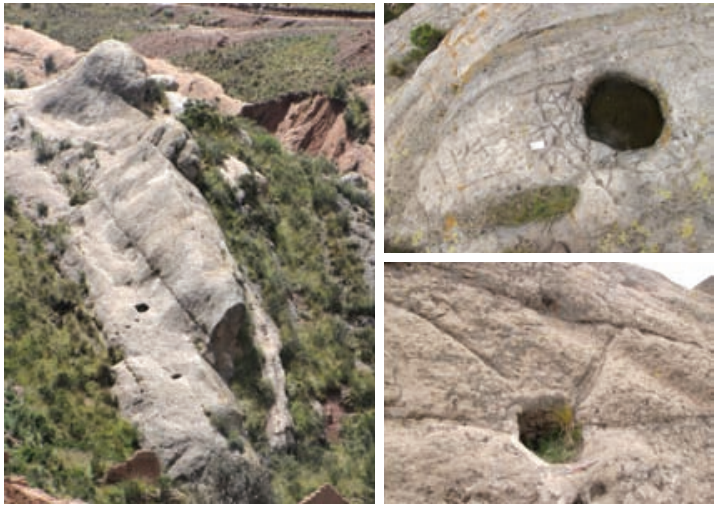

Figura 12. Corocoro de Pacajes, afloramientos rocosos con oquedades, canales y grabados, en contexto de producción minera. Figure 12. Corocoro de Pacajes. Rock outcrops with cavities, grooves and engravings, in the context of mining operations.

menos) indígena que la otra, ni conservó en mayor (o menor) medida sus estructuras ancestrales. Tampoco implica que estas sociedades no se reconocieran en su alteridad o en las relaciones de poder y subalternidad que mantuvieron, compartiendo procedencias, historias y elementos culturales: lingüísticos en primer lugar, pero también religiosos. Sin embargo, hay una diferencia que resulta fundamental y que no puede ser ignorada o relativizada. Mientras que en Potosí la élite indígena estuvo integrada por cien, doscientos o cuatrocientos miembros según los momentos y las fuentes, los indios 

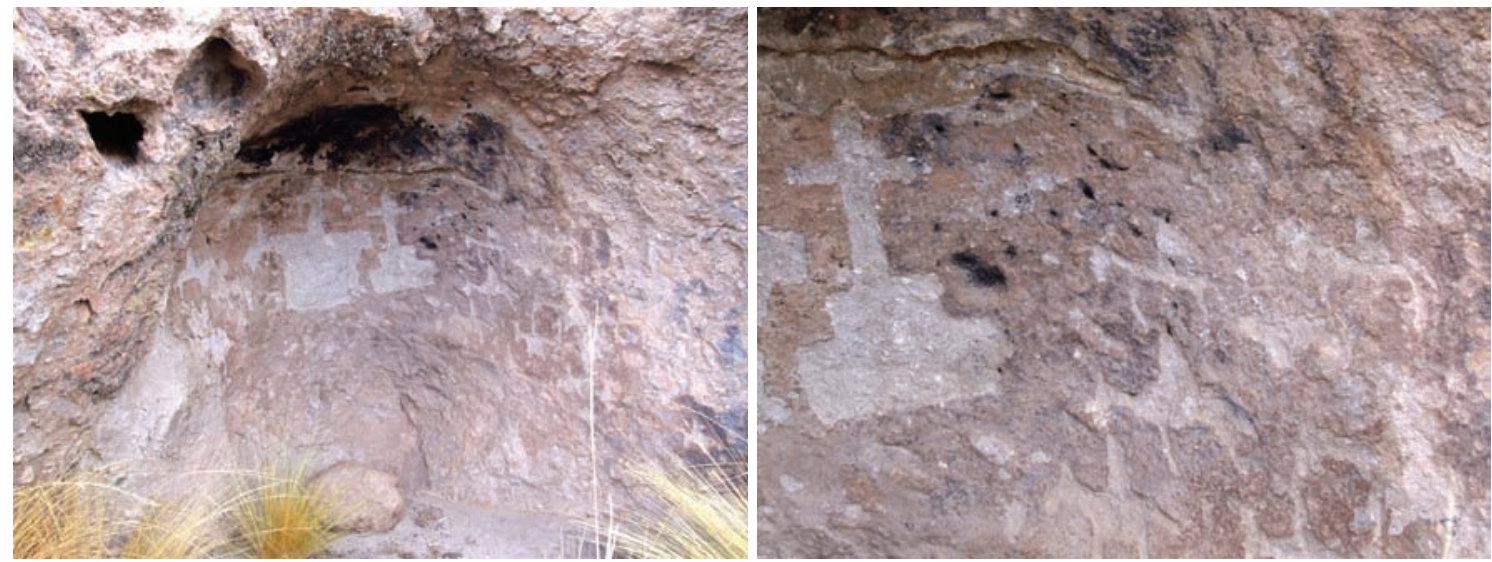

Figura 13. Thola Pampa, Yura, pequeño alero con grabados rupestres de jinetes en torno a una cruz con pedestal. Figure 13. Thola Pampa, Yura. Small rock shelter with engravings of horsemen around a cross with pedestal.

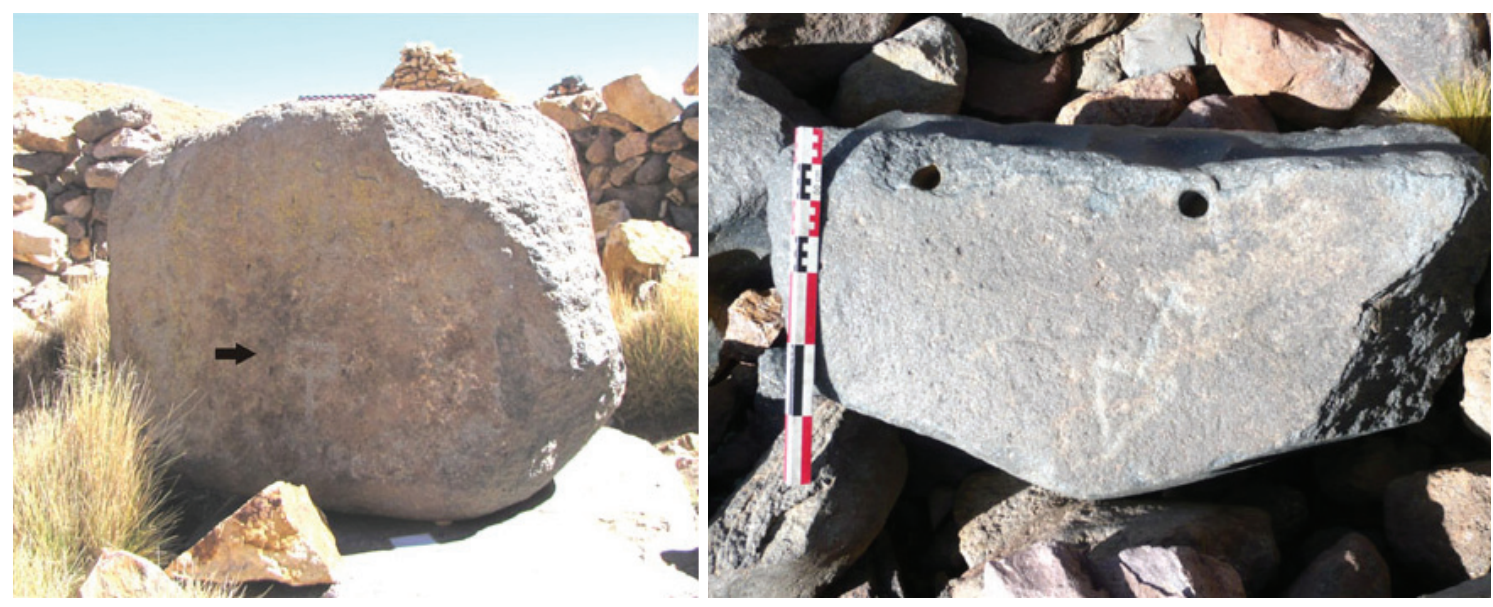

Figura 14. Guayco Seco, San Antonio de Lípez, elementos activos de quimbaletes con grabados de cruces con pedestal. Figure 14. Guayco Seco, San Antonio de Lípez. Active elements of quimbaletes (ore crushing stones) with engravings of crosses with pedestals.

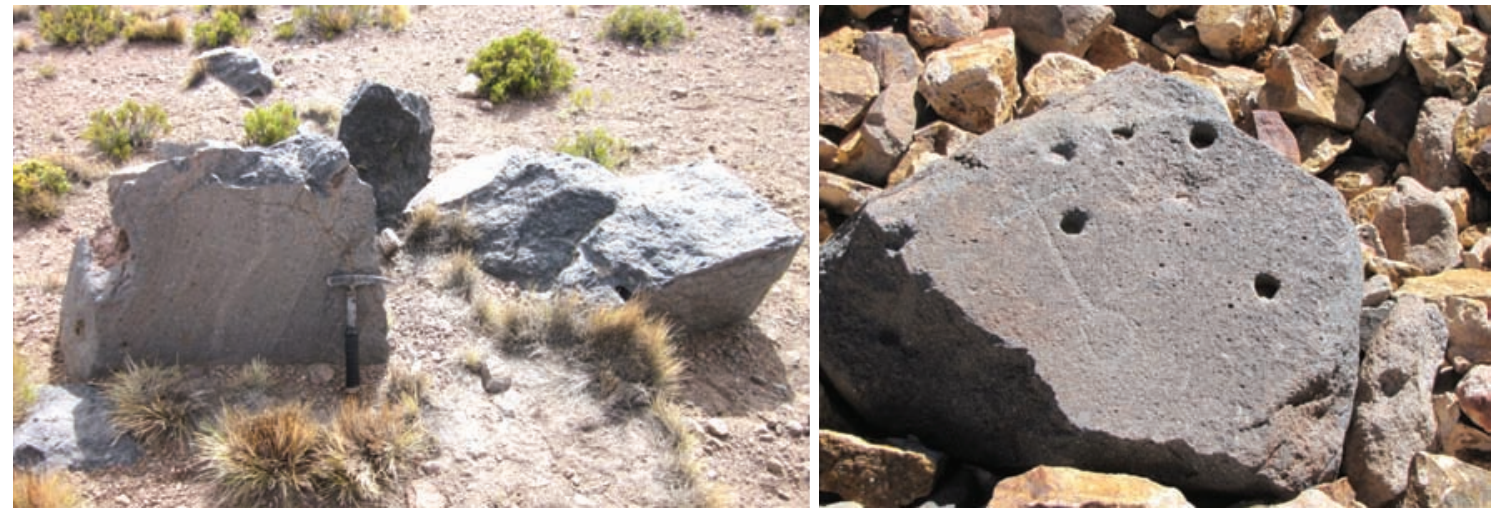

Figura 15. Guayco Seco, San Antonio de Lípez, rocas con diseños serpentiformes, perforaciones y grabado de cruz con pedestal intencionalmente destruidas. Figure 15. Guayco Seco, San Antonio de Lipez. Rocks with snake-like designs, drilled holes and an engraving of a cross with a pedestal, intentionally destroyed. 

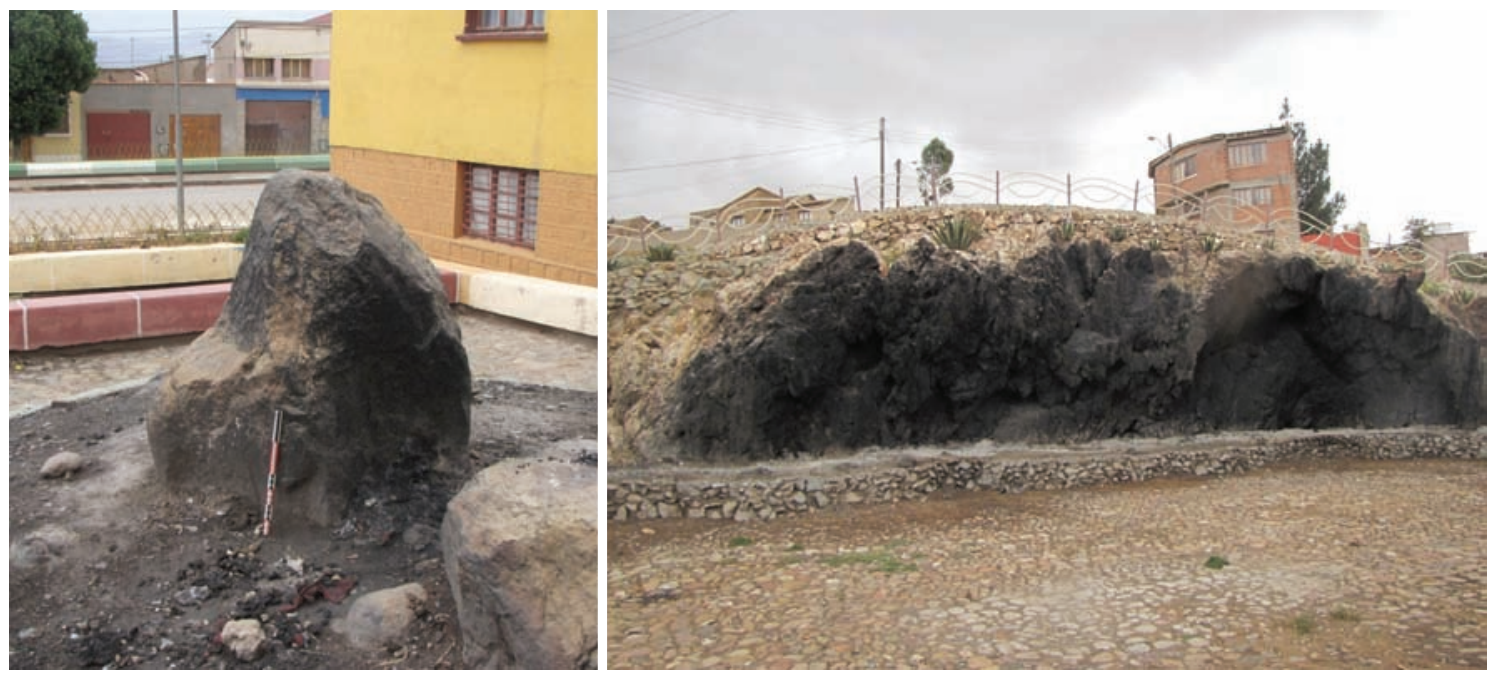

Figura 16. Fotografias de los hitos religiosos llamados El Sapo y La Serpiente en Oruro. Figure 16. Photographs of religious landmarks, named "El Sapo" (the Toad) and "La Serpiente" (The Snake), in Oruro.

del común alcanzaron respectivamente veinte mil, cuarenta mil u ochenta mil almas. Muy probablemente estas proporciones poblacionales fueron semejantes en otros centros mineros, tales como Oruro, San Antonio de Lípez y Chocaya.

Así, una de las respuestas a la primera pregunta es que, reconocidos sus linajes y derechos de sangre, y plenamente integrados dentro del sistema colonial, la élite indígena establecida en estos centros no se vio afectada por la iconoclasia que acompañó la evangelización y extirpación de idolatrías de la misma manera y con la misma intensidad que otras poblaciones indígenas, considerablemente más numerosas, y por ende, susceptible de portar un mayor peligro para los intereses de la Corona. Por el contrario, tal como hemos visto, representaciones de los antiguos Inkas gobernantes y símbolos de poder de marcado sentido religioso vinculados con los mismos resultaron más valorados que tolerados, ocupando un importante rol dentro de una narrativa cuya finalidad estuvo en la legitimación del Rey y del estado colonial, la cual comenzó a perfilarse muy poco tiempo después del establecimiento de los españoles. No obstante, muy probablemente estas representaciones y símbolos insertos dentro de la narrativa inkanista tuvieron diferentes niveles y sentidos de lectura, pudiendo resultar algunos, incluso, contrarios para la Corona. Tal podría ser el caso de algunos qeros pintados que exponen complejos relatos visuales que exaltan la figura del Inka. No obstante, trátese de desfiles u obras teatrales, de cuadros e ilustraciones en libros, de blasones nobiliarios, o bien de qeros pintados, estas representaciones y símbolos no circularon en otros contextos y soportes que aquellos particulares a las élites españolas e indígenas.

Tal situación nos conduce a responder la segunda pregunta formulada al comienzo del trabajo: ¿por qué estas representaciones y símbolos asociados con las élites indígenas, partícipes del régimen colonial, no aparecen igualmente en aquellas producciones visuales vinculadas con los indios del común que poblaron estos enclaves mineros? La pregunta puede tener varias respuestas. Por un lado, es posible que ambas sociedades indígenas compartieran la idea de que estas imágenes referidas al Inka y su simbología estuviesen restringidas a ciertos soportes y ámbitos de circulación específicos, siendo incluso producidas solo por determinadas personas. Por otro lado, y sin contradecir necesariamente lo anterior, tales ausencias podrían también resultar de una resistencia a reproducir imágenes referidas a una élite indígena compenetrada con el poder colonial. Es importante tener en cuenta aquí que prácticamente desde sus inicios los indios afectados a las minas e ingenios de Potosí buscaron subvertir el orden colonial establecido, tendiendo emboscadas a los españoles y sumándose a bandos sediciosos en contiendas y enfrentamientos, pero también robando minerales para luego venderlos clandestinamente en el mercado del Gato (Qat'u), o bien desertando de sus labores para ocultarse en waycos y quebradas o convirtiéndose en indios forasteros. Más 
tarde, durante la primera mitad del siglo xviI, Potosí, como varios otros centros mineros andinos, fue escenario de tempranos levantamientos y rebeliones conducidos por indígenas y mestizos ${ }^{17}$ que, al igual que las grandes rebeliones indígenas del siglo XVIII, desafiaron por igual la autoridad de la Colonia y de las élites indígenas aliadas con ésta (Thomson 2002; Serulnicov 2003). Finalmente, otra respuesta puede encontrarse en la gravitación que tuvo el accionar de la Iglesia, la cual tuvo entre sus principales misiones la conversión de las almas y la erradicación de los antiguos cultos indígenas, potencialmente latentes en estos espacios que congregaron una importante población de indios de distintos orígenes. Sobre todo tratándose de Potosí, en palabras del cura Bartolomé Álvarez, el "mercado que trata a la puerta del infierno", a la vez que la Babel "donde paran todas las cosas del reino, y donde hay más males que en todo el reino juntamente" (1998 [1588]: 352). Pero al mismo tiempo, contrabalanceando en gran medida el poder de los funcionarios de la Corona y el de los empresarios españoles, la Iglesia se constituyó como uno de los pocos amparos para los indígenas frente a los abusos del sistema colonial, particularmente en lo que refiere a los maltratos y vejaciones que implicaba la labor en las minas e ingenios. Un posicionamiento que sin duda favoreció el arraigo de la Iglesia en una sociedad indígena recientemente evangelizada. Mantener calmados los espíritus de los mineros indígenas, alejados de las idolatrías y de los "alborotos" sediciosos fue importante también para garantizar la "paz y tranquilidad del mineral", una condición requerida para que las vetas se reprodujeran según la concepción de la minería que se tenía por entonces, más próxima de la agricultura que de la geología (Cruz et al. 2011). Prueba de la importancia que tuvo mantener esta condición, bajo el argumento de "pacificar el mineral " en los años 1650, es que el estado colonial no tuvo mayores reparos en dictaminar la destrucción del asiento minero de Wayqo Seco, contiguo a San Antonio del Nuevo Mundo, evento que pudimos confirmar desde la arqueología. ${ }^{18}$

Veamos ahora qué nos dicen las producciones visuales indígenas presentes en contextos coloniales vinculados con la labor de las minas. Por el lado de la cerámica, que como hemos visto se relaciona mayormente con poblaciones oriundas del Collao que fueron trasladadas a los centros mineros surandinos, notamos la vigencia de ciertas tradiciones prehispánicas durante el siglo XVI y las primeras décadas del xVII, particularmente en lo que se refiere a los estilos Inka, Chilpe, Pacajes y Colla o Altiplánico. Asimismo, la cerámica que identificamos como Qolla Tardío I y II, surgida en los primeros años de la Colonia, muestra algunas continuidades con los estilos prehispánicos citados, ante todo en diseños que constituyeron significantes irreducibles tales como las espirales y las líneas en zigzag onduladas con puntos intercalados. En menor medida, aparecen en la cerámica Qolla Tardío II nuevos diseños figurativos que representan animales y seres míticos como el amaru, probablemente inspirados por otros soportes indígenas como textiles y qeros. No obstante, estos estilos irían desapareciendo de manera progresiva durante el siglo XVII, siendo reemplazados por cerámicas más rústicas o con superficies vitrificadas, de las cuales solo algunas estarían decoradas con diseños que remiten a los antiguos significantes, como las volutas espiraladas y los apliques de líneas en zigzag onduladas.

Diferente es el caso en el arte rupestre, donde se observa una mayor discontinuidad con aquellas tradiciones y estilos prehispánicos regionales, y en el que aparecen los diseños de cruces cristianas, mayormente grabadas, como principal referente. A diferencia de los sitios con arte rupestre localizados en distintas áreas rurales de la región, no se registraron en estos contextos imágenes de cruces superpuestas sobre otros diseños anteriores que sugieran una intención iconoclasta. Más bien, ellas aparecen de manera aislada o bien junto a diseños figurativos, en rocas visualmente relacionadas con la montaña de Potosí, o en soportes ubicados en lugares que tuvieron una particular connotación simbólica, como peñas, abrigos y quebradas de acceso. Sólo en San Antonio de Lípez hemos registrado grabados de cruces en rocas portando perforaciones y diseños serpentiformes que fueron intencionalmente destruidas. No obstante, no sabemos si tales cruces formaron parte de tales acciones destructivas, o si por el contrario reafirmaron la naturaleza especial de tales soportes con posterioridad a la destrucción ejercida sobre ellos. Por otro lado, se destacan una serie de producciones visuales en soportes rupestres que serían particulares de estos enclaves mineros: conjuntos de perforaciones, horadados, nichos y diseños serpentiformes, etc. Tales producciones visuales, que tienen por principal atributo su discreción visual, y que en muchos casos resultan imperceptibles si no se cuenta con información previa, estarían vinculadas con antiguos cultos a las montañas y cerros minerales, posiblemente en continuidad con 
algunas prácticas religiosas desarrolladas en tiempos del Inka, tal como lo sugieren las rocas con horadados y diseños serpentiformes registradas en algunos cerros minerales de la región que albergan adoratorios en sus cumbres (Cruz et al. 2013).

De manera general, y en relación con las respuestas a las dos preguntas que formulamos, vemos en estas producciones visuales tanto las consecuencias del control de las imágenes ejercido por la Iglesia y el sistema colonial en aquellas poblaciones de indios establecidas en los centros mineros, como las soluciones que surgieron ante el mismo. Es importante recalcar aquí el peso que tuvo la Iglesia en estos enclaves mineros, a diferencia de muchas áreas rurales que no tenían doctrina o se encontraban distanciadas de ellas, en su rol evangelizador, pero también en su defensa de los "indios del común" ante los abusos laborales y castigos físicos a los cuales eran sometidos en las minas e ingenios. Una de las consecuencias más claras se expone, a diferencia de aquellas imágenes referidas a la élite indígena, en la progresiva desaparición de tradiciones, estilos y significantes prehispánicos tanto en la cerámica como en el arte rupestre. Las soluciones, por un lado, se expresan en la incorporación y adecuación en el arte rupestre del símbolo de la cruz, que en estos contextos parece adoptar múltiples sentidos, pudiendo expresar la naturaleza especial del lugar o del soporte, la recepción y el arraigo de la nueva fe y el reconocimiento de su Iglesia. Cabe preguntarse si estas representaciones de cruces, ciertamente indígenas a la vez que plebeyas, no habrían sido también, en alguna medida, expresiones contrarias al régimen colonial, reflejando desde una posición subalterna las múltiples y variadas tensiones y conflictos que existieron entre la Iglesia, la Corona y la élite minera. Por otro lado, las soluciones se manifiestan en la discrecionalidad visual que presentan aquellas otras producciones visuales que hemos tratado. Si bien -como fue expresado por Martínez Cereceda (2009)- el arte rupestre fue un soporte de expresión indígena que tuvo poco interés para los españoles, en estos contextos muy poblados y particularmente coercitivos para las poblaciones indígenas, estas expresiones rupestres tuvieron prácticamente que invisibilizarse para pasar desapercibidas. No obstante, ello no fue algo que siempre se lograse, tal como atestiguan las rocas con imágenes que fueron destruidas en San Antonio de Lípez. Es en el marco de esta pugna de imágenes que muchos wakias y antiguos espacios de culto lograron mantenerse vigentes al despojarse de todo diseño que pudiera revelar su naturaleza, siendo identificados en estos casos únicamente por los rastros que dejaron, precisamente, sus cultos. Tal es el caso, por ejemplo, del sapo y la serpiente de Oruro (fig. 16), hoy importantes hitos en la cartografía religiosa de la ciudad minera y objetos de constantes rituales, testimonios materiales de relatos ontológicos que remiten a la victoria del cristianismo sobre los antiguos cultos prehispánicos, respectivamente solo una roca y una pared rocosa oscurecidas por una mezcla de sangres y humos ofrendados.

\section{NOTAS}

${ }^{1}$ Por tanto, se trata de enclaves como Potosí, San Antonio de Lípez, Oruro y Chocaya, los cuales se constituyeron en sus respectivos momentos como principales centros económicos, demográficos y culturales, y que tuvieron como principal población a indígenas de diferentes orígenes, muchos de ellos vinculados con los inkas del Cuzco y del Collao.

${ }^{2}$ Por ejemplo, en abril de 1555 (proclamación de los santos patronos de Potosí y Corpus Christi), en enero de 1590 (colocación del nuevo templo de la Compañía de Jesús), en Mayo de 1599 (fallecimiento de Felipe II), en Enero de 1600 (entronización de Felipe III), entre otras celebraciones posteriores.

${ }^{3}$ Tal fue el caso, por ejemplo, de las celebraciones que siguieron a la proclamación de los santos patronos de Potosí. Según nos cuenta Arzáns: “...Iban por delante 15 compañías de indios con sus capitanes ricamente vestidos a su usanza, con arcos y flechas, espadas de chunta $\mathrm{y}$ otras maderas fuertes todas plateadas, dardos, hondas, macanas y aquellas armas a manera de cimitarras que usaban los capitanes de sus ingas; toda esta variedad de indianas armas iban unas doradas, plateadas otras, y otras vistosamente coloreadas. Luego se seguía un acompañamiento imitando el que tenían los monarcas ingas en su corte, el cual iba compuesto de la nobleza indiana que en esta villa asistía. Serían éstos más de 200 hombres vestidos a su uso, aunque eran las camisetas y mantas de ricas sedas, y traían por su orden las insignias reales, en unas hamacas de finas mantas de algodón, las cuales era el llautu y la borla (que era la corona de aquellos poderosos monarcas), las arracadas, chaquiras, pomares y licras (que eran una máscaras de cabeza de león, que formadas de oro finísimo se ponían en los hombros, rodillas y empeines), el arco, carcaj y flechas, hondas, el chambe, y el cuadrado escudo, con otras insignias y armas reales. Luego con toda majestad venían de dos en dos todos los monarcas ingas hasta el poderoso Atahuallpa, con aquel excelente traje, llevando cada un hacha de cera en la mano..." (Arzáns 1965 [1737] I: 96).

${ }^{4} \mathrm{~A}$ los pocos meses de su fundación, la ciudad de Potosí congregaba tres mil indígenas, en 1561 aproximadamente veinte mil y en 1611 cerca de cien mil.

${ }^{5}$ Estos yndios están guayrando, anónimo, siglo xvi. The Hispanic Society of América.

${ }^{6}$ The silver mines of Potosí, anónimo de 1585. The Hispanic Society of America.

${ }^{7}$ Entre ellos, la Descripción del Cerro Rico e Villa Imperial de Potosí de Gaspar Miguel Berrios, 1758. 
${ }^{8}$ Así lo refieren autores como Capoche (1959 [1585]: 141): “... Acostumbran estos a beber en público juntándose mucha gente, así hombres como mujeres, los cuales hace grandes bailes en que usan de ritos y ceremonias antiguas, trayendo a la memoria en sus cantares la gentilidad pasada. Y como duran los saraos días y noches, o por mejor decir, toda la vida, cuando acaban no conocen los padres a las hijas ni los hijos a las madres, y en esto hay grandes males..., y Ocaña (1987: 204-205): “...Todo un ayllo, que es decir todos los de una parentela; y con un tamboríl en medio de todos, que están hechos una rueda, dados de las manos unos con otros, andan danzando indios e indias, toda la noche... sin cesar, ni cesa el baile, hasta que se acaba la chicha y toda cuanta plata tienen. Y a cualquiera hora de la noche, se oyen los tamborines de las rancherías y como van dando vueltas bailando, van bebiendo todos, ansí varones como mujeres, hasta que se acaban las botijas de la chicha y quedan tan borrachos ellos y ellas que como puercos quedan por aquellos suelos...."

9 “...Yten porque la ymbencion de la harina de mayz que en pocos años a esta parte se an seguido muchos daños convinientes ansi a la lavor de las minas como gran a los yndios e ympedimento para su convercion y por conservacion a los que se an convertido porque como es cada año entran en esta villa treinta mil fanegas de harina de mayz y mas toda se haze chicha y se bebe casi toda la semana en borracheras y no son poderosos los jueces para se las quitar por que no aprovecha hazer los castigos crueles antes dizen que por que los cristianos quitan el emborracharse pues ellos les dierron la ymbencion de la harina y es causa que no suban a las minas y de empobrecerse los yndios y no tener hazienda ni caudales y estando en su juizio es gente aplicada a travajar y estando borrachos cometen omicidios e ynsestos con sus madres y hijos y hermanos y adulterios y matan a sus mugeres y muchos mueren de la borrachera y se tornan locos y cometen ydolatrias y se les acuerda de sus malos ritos y buelven a ellos a se pedido a la audiencia se mande quitar dicha harina y no lo an proiveydo sospechase que la causa es porque muchos vezinos de la ciudad de la plata tienen molinos y son principales haziendas y si se quitase la harina del maiz pederian mucho..." (Memorial sobre las cosas de Potosí y sus remedios, BN 3040:82v-83f, transcripción nuestra).

${ }^{10}$ Arzáns (1965 [1737]: I 304-305) cuenta que en el año 1681 la calle donde se localizaban las chicherías era llamada Supay calle (calle del diablo o demonio) en razón de que en ella “...estaban muchos indios en regocijo bailando y los demonios con ellos en medio de la rueda en figura de estos naturales; en la segunda vi aquellos infernales espíritus tendidos como durmiendo a las puerta de las tiendas de chichería que hay en aquella calle [...]".

${ }^{11}$ Por ejemplo, Arzáns se refiere al carácter idolátrico que poseían estos lugares en el año 1566, y los relacionan con prácticas homosexuales: “...Eran dos y entrambos casados, y (como después declararon algunos católicos indios) eran apóstatas y se habían vuelto a las costumbres de sus padres, que era la idolatría y otros pecados muy sucios..." Entre ellos cometían el pésimo y abominable nefando, y por no tener impedimento en tan grave maldad se salían de esta villa y se iban unas veces al Arenal, otras a Tarapaya y otras a Carachipampa: allí cometían el pecado varón con varón, y mujer con mujer..." (Arzans 1965 [1737]: 129, año 1566). No está claro dónde termina la cita (hay dos términos distintos).

${ }^{12}$ Así fue señalado, por ejemplo, por el Lic. Cepeda: “...Lo tercero que los caciques con calor de sembrarles porque no se den a españoles ponen en ellas y en los guaycos gran cantidad de yndos sacandoles de sus pueblos y rreducciones ocumadoles todo el año en cossas de sus interes y chacaras que para ellos les hazen sembrar para lo cual hazen los misserables yndios unos compelios y otros de voluntad porque dexen sin doctrina ydolatrando en sus guacas antiguas haziendo sus borracheras ofendiendo a Dios padres con hijas hijos con madres hermanos con hermanas sin tener quien les vaya a la mano a estas maldades y otras semejantes..." (Representación al Virrey del Lic. Cepeda sobre el remedio de los escándalos y excesos de Potosí, BN 3040: 69v, transcripción nuestra).

${ }^{13}$ Es importante recalcar aquí la vigencia que tuvieron, como gran parte de la cultura material, los estilos cerámicos prehispánicos durante el periodo de contacto y los primeros momentos de la Colonia, al llegar incluso hasta las primeras décadas del siglo xvir. La perduración de estas tradiciones, susceptible de ocasionar problemas de interpretación, fue señalada tanto para los diferentes estilos inkaicos, como para aquellos estilos regionales tales como Colla o Altiplánico, Pacajes y Chillpe (Tshopik 1946; Hyslop 1976; Julien 1983; Van Buren 1993; Chacama 2005; Weaver 2008; Cruz \& Téreygeol 2014), entre otros estilos.

${ }^{14}$ Por ejemplo, este estilo fue identificado como grupo Chocasu en el área de Juli-Desaguadero (Stanish et al. 1997: 31 y ss.), Colonial Temprano en la península de Taraco, en continuidad con los estilos prehispánicos Chucuito negro sobre rojo y Pacajes (Bandy 2001; Bandy \& Janusek 2005) y como la Fase 4 (Periodo de Contacto) en el área de Hatunqolla (Julien 2004).

${ }^{15}$ De manera general la morfología de estos platos y escudillas exponen una clara influencia europea que es, en todo caso, desconocida en las precedentes tradiciones prehispánicas.

${ }^{16}$ Tal como sucede con varios estilos cerámicos y otras tradiciones prehispánicas, es importante tener en cuenta aquí la vigencia que tuvieron los adoratorios de altura inkaicos durante los primeros momentos de la Colonia, al punto de que incluso pudo haberse intensificado las prácticas rituales desarrolladas en ellos. Así lo señalan, por ejemplo, las estructuras votivas coloniales y ofrendas de leños asociados con el adoratorio que se ubica en la cumbre del cerro Mundo, el cual se encuentra próximo de los cerros Cuzco, Cosuña y Tunupa aquí citados. Dos muestras de estas ofrendas de leños fueron datadas por dendrocronología dando como resultado las fechas de 1540 y 1575 (Cruz 2013). Asimismo, autores coloniales como Hernández Príncipe (1923 [1621]) refieren a rituales de capacocha, tal como el caso donde resultó sacrificada Tanta Carhua, desarrollados en los años que siguieron el desembarco de los españoles.

${ }^{17}$ Entre las más importantes las rebeliones de Potosí (16221625), Caylloma (1629-1630), Chocaya (1634-1636), Carangas (1640), San Antonio de Esquilache (1650), Guayco Seco-San Antonio de Lípez (1655?), Lakaycota (1665-1668).

${ }^{18}$ Tal determinación aparece en el "Expediente sobre el desagüe del socavón del mineral de los Lipes” (1675-1678) AGI, Charcas, 23, R.6, N.41 (ver Bakewell 1988: 81-99; Cruz et al. 2011).

\section{REFERENCIAS}

Absi, P. \& P. CRUz, 2007. La porte de la wak'a de Potosi s'est ouverte à l'enfer. La quebrada de San Bartolomé. Journal de la Société des Américanistes 93 (2): 51-86.

Álvarez, B., 1998 [1588]. De las costumbres y conversión de los indios del Perú. Memorial a Felipe II, M.C. Martín; J. Villarías \& F. del Pino, Eds. Madrid: Ediciones Polifemo.

Arriaga, P., 1958 [1621]. La extirpación de la idolatría en el Perú. Lima: Colección de libros y documentos referentes a la historia del Perú. 
Arzáns de Orzúa \& B. Vela, 1965 [1737]. Historia de la Villa Imperial de Potosí, L. Hanke \& G. Mendoza, Eds. Rhode Island: Brown University Press.

BAKEWELL, P., 1988. Silver and entrepreneurship in seventeenth-century Potosi, the life and times of Antonio López de Quiroga. Cambridge: University of New Mexico Press.

BANDy, M., 2001. Population and history in the ancient Titicaca basin. Ph.D. Dissertation, Department of Anthropology, University of California, Berkeley. [online].

http://citeseerx.ist.psu.edu/viewdoc/download?doi=10.1.1.113. 5003\&rep=rep1\&type=pdf [Citado 20-03-2015].

Bandy, M. \& J. Janusek, 2005. Settlement Patterns, administrative boundaries, and internal migration in the early Colonial period. En Avances en la arqueología de la cuenca del Titicaca-I, C. Stanish, A. Cohen \& M. Aldenderfer, Eds., pp. 267-288. Los Ángeles: Cotsen Institute of Archaeology Press.

Bouysse-Cassagne, T., 1987. La identidad aymara. Aproximación histórica (siglo XV-siglo XVI). La Paz: HISBOL-IFEA.

Bouysse-Cassagne, T., 2004. El sol de adentro: Wakas y santos en las minas de Charcas y en el lago Titicaca (siglos xv a XVII). Boletín de Arqueología PUCP 8: 59-97.

Bouysse-Cassagne, T., 2005. Las minas del centro-sur andino, los cultos prehispánicos y los cultos cristianos. Boletín del Instituto Francés de Estudios Andinos 34 (3): 443-462.

Bouysse-Cassagne, T., 2008. Minas del sol, del Inka, y de la gente. Potosí en el contexto de la minería prehispana. En Minas y metalúrgias en los Andes del Sur, entre la época prehispánica y el siglo XVII, P. Cruz \& J. Vacher, Eds., pp. 278-301. Sucre: IFEA-IRD.

CApoche, L., 1959 [1585]. Relación general de la Villa Imperial de Potosí. Madrid: Biblioteca de Autores Españoles.

Chacama, J., 2005. Patrón de asentamiento y uso del espacio. Precordillera de Arica, extremo norte de Chile, siglos x-xv. Boletín del Instituto Francés de Estudios Andinos 34 (3): 357-378.

CRUZ, P., 2006. Mundos permeables y espacios peligrosos. Consideraciones acerca de punkus y qaqas en el paisaje altoandino de Potosí, Bolivia. Boletín del Museo Chileno de Arte Precolombino 11 (2): 35-50.

CRUZ, P., 2009. Huacas olvidadas y cerros santos. Apuntes metodológicos en torno a la cartografía sagrada en los Andes del sur de Bolivia (Potosí, Chuquisaca). Estudios Atacameños 38: 55-74.

Cruz, P., 2015. Tatala Purita o el influjo del rayo. Arte rupestre anicónico en las altas tierras surandinas (Potosí, Bolivia). Boletín Sociedad de Investigación de Arte Rupestre de Bolivia 29: 51-70.

Cruz, P. \& P. ABsi, 2008. Cerros ardientes y huayras calladas Potosí antes y durante el contacto. En Mina y Metalurgia en los Andes del Sur. Desde la Época Prehispánicas hasta el siglo XviI, P. Cruz \& J. Vacher, Eds., pp. 91-121. Sucre: IRD-IFEA.

CRUZ, P. \& F. Téreygeol, 2014. Yanaconas del rayo: Reflexiones en torno a la producción de metales en el espacio surandino (Bolivia, siglos XV-XVI). Estudios Atacameños 49: 19-44.

Cruz, P.; A. Nielsen; F. Téreygeol; J.P. Deroin \& I. Guillot, 2011. La pacificación del mineral. Cerro Lípez, un enclave minero en la contienda sobre el Nuevo Mundo. Vestigios. Revista Latinoamericana de Arqueología Histórica 6: 11-44. Minas Gerais.

Cruz P.; E. Crubezy \& P. Gerard., 2013. Los adoratorios de altura inkaicos: Una mirada desde el cerro Cuzco, departamento de Potosí, Bolivia. Memoria Americana 21 (1): 93-120. Buenos Aires. [online]. http://www.scielo.org.ar/scielo.php?script=sci_arttex t\&pid $=\$ 185137512013000100004 \& \operatorname{lng}=e s \& n r m=$ iso $>$ [Citado 10-04-15].
Cummins, T., 2004. Brindis con el Inca. La abstracción andina y las imágenes coloniales de los queros. Lima: Universidad Nacional Mayor de San Marcos-Universidad Mayor de San Andrés-Embajada de los Estados Unidos de América.

Escobari de QueRejazu, L., 2011. Mano de obra especializada en los mercados coloniales de Charcas. Bolivia, siglos XvI-XviI. Nuevo Mundo Mundos Nuevos. Débats. París. [online].

http://nuevomundo.revues.org/60530 [Citado 12-04-15].

Espinoza Soriano, W., 1972. Copacabana del Collao. Un documento de 1548 para la etnohistoria andina. Boletín del Instituto Francés de Estudios Andinos 1: 1-16.

Estenssoro, J. C., 2003. Del paganismo a la santidad: La incorporación de los indios del Perú al catolicismo, 1532-1750. Lima: IFEA-PUCPInstituto Riva-Agüero.

Fuente Sanct Ángel, R., 1965 [1572]. Relación del cerro de Potosí y su descubrimiento. En Relaciones geográficas de Indias, tomo II, M. Jiménez de la Espada, Comp., pp. 357-361. Madrid: Biblioteca de Autores Españoles.

Gisbert T., 2004. La Virgen-Cerro y el Dios Pachacamac. Revista Cultural 30: 21-27. La Paz: Fundación Banco Central de Bolivia.

Gisbert, T. \& J. Mesa, 1977. Holguín y la pintura virreinal en Bolivia. La Paz: Editorial Juventud.

Godoy VegA, F., 2012. Anatomías territoriales. Alternativas de activar la otredad de pinturas coloniales de Potosí. Revista Historia y Memoria 4: 47-91. Boyacá: Universidad Pedagógica y Tecnológica de Colombia.

Guaman Poma de Ayala, F., 1989 [1615]. El primer nueva corónica $y$ buen gobierno. París: Institut d'Ethnologie.

Hernández Príncipe, R., 1923 [1621]. Mitología Andina. Idolatrías en Recuay. Revista Inca 1 (1): 25-78. Lima.

HysLop, J., 1976. An archaeological investigation of the Lupaqa kingdom and its origins. Tesis para optar al grado de Doctor, Departamento de Antropología, Columbia University, New York.

Julien, C., 1983. Hatunqolla: A view of Inca rule from the lake Titicaca region. Berkeley: University of California Press.

Levillier, R., 1935. Don Francisco de Toledo, supremo organizador del Perú, su vida, su obra, 1515-1582. Buenos Aires: Biblioteca del Congreso Argentino-Espasa-Calpe.

MACCHI, F., 2009. Incas ilustrados: Reconstrucciones imperiales en la segunda mitad del siglo xviII. Madrid-Frankfurt: IberoamericanaVervuert.

Martínez C. J. L., 2009. Registros andinos al margen de la escritura: El arte rupestre colonial. Boletín del Museo Chileno de Arte Precolombino 14 (1): 9-35.

Martínez C., J. L; C. Díaz; C. Tocornal \& V. Arévalo, 2014. Comparando las crónicas y los textos visuales andinos. Elementos para un análisis. Chungara 46 (1): 91-113.

Medinacelli, X., 2007. Paullu y Manco ¿una diarquía inca en tiempos de conquista? Boletín del Instituto Francés de Estudios Andinos 36 (2): 241-258.

Medinacelli, X., 2010. Sariri: Los llameros y la construcción de la sociedad colonial. La Paz: IFEA-Plural-ASDI-Instituto de Estudios Bolivianos.

Millones, L., (Ed.) 1990. El retorno de las huacas. Estudios y documentos sobre el Taqui Oncoy, siglo XVI. Lima: Instituto de Estudios Peruanos-Sociedad Peruana de Psicoanálisis.

MurúA, M., 2004 [1590]. Códice Murúa: Historia y genealogía de los Reyes Incas del Perú del padre mercedario Fray Martín de Murúa: Códice Galvin, J. Ossio, Ed. Madrid: Testimonio Compañía Editorial.

OcaÑA, D., 1987 [1605]. A través de la América del Sur. Madrid: Historia 16. 
Platt, T. \& P. Quisbert, 2008. Tras las huellas del silencio: Potosí, los incas y el virrey Toledo. En Mina y Metalurgia en los Andes del Sur. Desde la Época Prehispánicas hasta el siglo xvII, P. Cruz \& J. Vacher, Eds., pp. 231-277. Sucre: IFEA-IRD.

Platt, T.; T. Bouysse-Cassagne \& O. Harris, 2006. QaraqaraCharka. Mallku, inka y rey en la provincial de Charcas (siglos $\mathrm{XV}$-XVII): Historia antropológica de una confederación aymara. La Paz: IfeA-Plural-University of St. Andrews-University of London-Inter American Foundation-Fundación Cultural del Banco Central de Bolivia.

Posnansky, A., 1945. Tihuanacu: La Cuna del Hombre Americano. New York: J. J. Augustin.

QuisBert, P., 1988. En el umbral de la frontera. Diego Rodríguez de Figueroa. Un intérprete de dos mundos en el Potosí del siglo Xvi. Historias 2: 149-167.

Quisbert, P., 2015. Potosí y el fantasma de Vilcabamba. En Andes, Amazonas y sus transformaciones.Comparaciones, conexiones, fronteras entre las tierras altas y bajas de Sud América. T. Platt, G. Rivière \& I. Daillant, Eds. St. Andrews: Centre for Amerindian Studies-School of Philosophical and Anthropological Studies.

SAIGNES, T., 1987. De la borrachera al retrato: Los caciques andinos entre dos legitimidades (Charcas). Revista Andina 5 (1): 139-170.

SAignes, T., 2003 (Comp.). Borrachera y Memoria. La experiencia de lo sagrado en los Andes. La Paz: IFEA-HISBoL.

Santos Escobar, R., 1987. La contribución de Apu Chalco Yupanki, gobernador del Kollasuyu en la expedición de Diego de Almagro a Copiapó, principio de Chile. Colección de Folletos Bolivianos de Hoy III (24). La Paz.
SERULNiKOv. S., 2003. Subverting colonial authority-challenges to spanish rule in eighteenth-century southern Andes. Durham: Duke University Press.

Stanish, C.; E. de la Vega; L. Steadman; C. Chávez; K. Frye; I. Onofre Mamani; M. Seddon \& P. Calisaya, 1997. Archaeological survey in the Juli-Desaguadero region of the Lake Titicaca basin, southern Peru. Chicago: Field Museum of Natural History Press.

Thomson, S., 2002. We alone will rule. Native andean politics in the age of insurgency. Wisconsin: The University of Wisconsin Press.

ToLEDo, F., 1882 [1570-72]. Informaciones acerca del señorío y gobierno de los ingas. Colección de libros españoles raros o curiosos (16), M. Jiménez de la Espada, Ed., pp. 177-259. Madrid: Miguel Ginesta.

Тsнорік, M., 1946. Some notes on the archaeology of the Department of Puno, Peru. Cambridge: The Museum.

Van Buren, M., 1993. Community and empire in Southern Peru; the site of Torata under spanish rule. Ph.D. Dissertation. University of Arizona, Tucson.

WeAver, B., 2008. Ferro ingenio: An archaeological and ethnoarchaeological view of labor and empire in colonial in Porco and Potosí. Tesis para optar al grado de Magíster, Western Michigan University, Kalamazoo. [online].

www.brendanweaver.net/anthro/Weaver_MA_Thesis_2008.pdf [Citado 15-06-2015].

WUFFARDEN, L.E., 2005. La descendencia real y el "renacimiento inca" en el virreinato. En Los Incas: Reyes del Peru, T. Cummins et al. Eds., pp. 175-251. Lima: Banco de Crédito del Perú. 